\title{
IMMUNOLOGICAL STUDIES ON PATIENTS WITH PNEUMOCOCCIC PNEUMONIA TREATED WITH SULFAPYRIDINE
}

\author{
By MAXWELL FINLAND, WILLIAM C. SPRING, JR., AND FRANCIS C. LOWELL \\ (From the Thorndike Memorial Laboratory, Second and Fourth Medical Services (Harvard), \\ Boston City Hospital and the Department of Medicine, Harvard Medical School, Boston)
}

(Received for publication September 5, 1939)

In a separate communication (1) we presented observations on the effect of sulfapyridine on the growth of Types I, III, and V pneumococci in a favorable artificial medium and in human blood to which it is added in vitro or which is obtained after its administraton. The chemical was shown to have marked bacteriostatic and considerable bactericidal action on these three types of pneumococci. The mechanism of action of sulfapyridine was found to differ fundamentally from that of homologous types of specific immune serum. The action of the latter occurs only in the presence of phagocytic cells and is most effective in freshly shed blood. The action of the former is independent of the immune mechanism. Immune serum was found to exert its bactericidal effect rapidly whereas the action of sulfapyridine was considerably delayed and could not be demonstrated in any instance until after growth of pneumococci had occurred. When small amounts of immune serum were combined with low concentration of sulfapyridine, the bactericidal action of fresh blood occurred rapidly and was greater than when either of these agents was added separately in comparable amounts. In the present paper are presented the results of immunological studies in patients with pneumococcic pneumonia who were treated with sulfapyridine. These studies were carried out in an attempt to elucidate the relationship, if any, of the immune state to the mechanism of recovery from pnuemonia in patients treated with this drug. Because of the wide variations in the antibody response of different patients to infections even of the same type and without serotherapy or chemotherapy and because of the paucity of available data, the results are presented for each type in considerable detail.

\section{MATERIALS AND METHODS}

The patients studied were all admitted to the medical wards of the Boston City Hospital during the 1938 to 1939 season. Only patients with clinical and x-ray evi- dence of pneumonia are included. In each instance a type-specific pneumococcus was obtained from the sputum on one or more occasions. Blood cultures were taken before and at frequent intervals after therapy was begun. When positive cultures were obtained from blood or from infected exudates the type of pneumococcus found confirmed the sputum findings in each instance. The clinical aspects of the treatment are left for separate consideration and only relevant data are included. The immunological and chemical methods were the same as those used in other recent studies in this laboratory (1). Control tests with heterologous types were carried out in many instances. Most of these were negative and are not reported unless relevant. Blood was obtained for culture and for the various immunological tests before treatment with sulfapyridine or with serum was started. In almost every instance where these agents were used in sequence blood samples were taken before the administration of each was begun. Further samples of blood were taken at intervals after the onset of therapy. In those bloods taken during the course of sulfapyridine administration, determinations of the concentration of this drug in the blood were done in addition to the immunological tests. Only a small number of cases treated with the combination of sulfapyridine and serum are included. The therapeutic serums used were mostly rabbit serums furnished by the Lederle Laboratories for clinical trial.

\section{RESULTS}

The bactericidal tests were carried out only in a limited number of cases of Types I, III, V, and VIII pneumococcic pneumonia and protection tests were done in cases with these types and also in a few Type II and Type VII cases. A total of 216 cases due to these 6 types was studied with protection and agglutination tests, including 87 in which bactericidal tests were also done. The cases to be presented in the tables are selected as examples of the varieties of response noted with each of the types. The studies in the remaining types were limited to tests for agglutinins. The results will be presented separately for each of the 6 common types.

Type I Cases. The results of the various tests in these cases are listed in Tables I and II and are shown graphically in Figures 1 and 2 . Cases 
TABLE I

Results of immunological studies in patients with preumococcus $T y$ pe I preumonia treated with sulfapyridine or with the combination of sulfapyridine and specific serum

\begin{tabular}{|c|c|c|c|c|c|c|c|c|c|c|c|c|c|c|c|c|}
\hline \multirow{3}{*}{ 离 } & \multirow{3}{*}{$\begin{array}{l}\text { Sex } \\
\text { and } \\
\text { age }\end{array}$} & \multirow{3}{*}{ Therapy } & \multirow{3}{*}{\begin{tabular}{|l} 
First \\
dose
\end{tabular}} & \multirow{3}{*}{$\begin{array}{l}\text { Inter- } \\
\text { val } \\
\text { first to } \\
\text { last } \\
\text { dose }\end{array}$} & \multirow{3}{*}{ Amount } & \multicolumn{9}{|c|}{ Results of tests } & \multicolumn{2}{|c|}{ Termination } \\
\hline & & & & & & \multirow{2}{*}{$\begin{array}{l}\text { Day } \\
\text { of } \\
\text { dis- } \\
\text { ease }\end{array}$} & \multirow{2}{*}{$\begin{array}{c}\text { Blood } \\
\text { cul- } \\
\text { ture }\end{array}$} & \multicolumn{2}{|c|}{$\begin{array}{l}\text { Blood sulfa- } \\
\text { pyridine }\end{array}$} & \multirow{2}{*}{\begin{tabular}{|} 
Growth \\
inhibi- \\
tion
\end{tabular}} & \multirow{2}{*}{$\begin{array}{l}\text { Pneu- } \\
\text { mococci } \\
\text { billed }\end{array}$} & \multirow{2}{*}{$\begin{array}{l}\text { Op- } \\
\text { sonic } \\
\text { index }\end{array}$} & \multirow{2}{*}{$\begin{array}{c}\text { Mouse } \\
\text { protec- } \\
\text { tion }\end{array}$} & \multirow{2}{*}{$\begin{array}{c}\text { Agglu- } \\
\text { tinins }\end{array}$} & \multirow{2}{*}{ Mode } & \multirow{2}{*}{ Day } \\
\hline & & & & & & & & Free & Total & & & & & & & \\
\hline 1 & M 12 & S.P. & \begin{tabular}{|} 
hours \\
afier \\
onset \\
52 \\
52
\end{tabular} & $\begin{array}{c}\text { hours } \\
66\end{array}$ & $\begin{array}{c}\text { grams } \\
12\end{array}$ & $\begin{array}{r}52 \\
68 \\
120\end{array}$ & $\begin{array}{l}\mathbf{0} \\
\mathbf{0}\end{array}$ & $m g m$. & 100 cc. & $\begin{array}{c}48 \\
\text { hours } \\
0 \\
10^{8} \\
10^{8}\end{array}$ & $\begin{array}{c}\text { at } 48 \\
\text { hours } \\
0 \\
10^{4} \\
10^{5}\end{array}$ & $\begin{array}{l}0 \\
0.2 \\
24.2\end{array}$ & $\begin{array}{c}0 \\
0 \\
10^{4}\end{array}$ & $\begin{array}{l}0 \\
0 \\
0\end{array}$ & Crisis & 83 \\
\hline 2 & M 28 & S.P. & 84 & 96 & 21 & $\begin{array}{r}75 \\
84 \\
102 \\
9\end{array}$ & $\begin{array}{c}+ \\
0 \\
0\end{array}$ & 5.6 & 8.2 & $\begin{array}{c}0 \\
10^{5} \\
10^{7}\end{array}$ & $\begin{array}{c}0 \\
10^{3} \\
10^{6}\end{array}$ & $\begin{array}{c}0.1 \\
0.04 \\
15.8\end{array}$ & $\begin{array}{c}0 \\
0 \\
10^{6}\end{array}$ & $\begin{array}{l}0 \\
0 \\
2\end{array}$ & Lysis & $\begin{array}{l}115- \\
131\end{array}$ \\
\hline 3 & M 37 & S.P. & 128 & 60 & 16 & $\begin{array}{r}127 \\
166 \\
13\end{array}$ & $\begin{array}{l}3 \\
\mathbf{0}\end{array}$ & 9.5 & 10.6 & $\begin{array}{l}10^{3} \\
10^{7} \\
10^{4}\end{array}$ & $\begin{array}{l}10^{3} \\
10^{6} \\
10^{4}\end{array}$ & $\begin{array}{c}0 \\
2.7 \\
18.3\end{array}$ & $\begin{array}{c}0 \\
10^{6} \\
10^{6} \times 10\end{array}$ & $\begin{array}{r}0 \\
4 \\
32\end{array}$ & Lysis & $7-15$ \\
\hline 4 & M 28 & S.P. & 32 & 96 & 21 & $\begin{array}{r}18 \\
32 \\
65 \\
100 \\
7 \\
8 \\
14\end{array}$ & $\begin{array}{l}\mathbf{0} \\
0 \\
0 \\
0\end{array}$ & $\begin{array}{l}6.4 \\
9.8 \\
3.5 \\
\text { Tr. }\end{array}$ & $\begin{array}{r}6.4 \\
11.6 \\
5.1 \\
\text { Tr. }\end{array}$ & $\begin{array}{l}10^{4} \\
10^{6} \\
10^{6}\end{array}$ & $\begin{array}{l}10^{4} \\
10^{6} \\
10^{5}\end{array}$ & $\begin{array}{c}0.24 \\
0 \\
10.4\end{array}$ & \begin{tabular}{|c|}
$10^{3}$ \\
10 \\
10 \\
0 \\
$10^{5}$ \\
$10^{6} \times 10$ \\
$10^{6} \times 50$
\end{tabular} & \begin{tabular}{|c}
0 \\
0 \\
0 \\
0 \\
4 \\
32 \\
$64+$
\end{tabular} & Crisis & 84 \\
\hline 5 & F 69 & S.P. & $\begin{array}{r}98 \\
101\end{array}$ & $\begin{array}{l}30 \\
23\end{array}$ & $\begin{array}{c}13 \\
580 \text { th.u. }\end{array}$ & $\begin{array}{r}98 \\
122 \\
19\end{array}$ & $\begin{array}{r}550 \\
0\end{array}$ & 4.3 & 8.8 & $\begin{array}{c}0 \\
10^{7} \\
10^{6}\end{array}$ & $\begin{array}{c}0 \\
10^{6} \\
10^{6}\end{array}$ & $\begin{array}{l}0.96 \\
36.5 \\
14.2\end{array}$ & & $\underset{8}{0}+$ & Lysis & $131+$ \\
\hline 6 & M 69 & $\begin{array}{l}\text { S.P. } \\
\text { Serum }\end{array}$ & $\begin{array}{l}58 \\
85\end{array}$ & $\begin{array}{l}36 \\
14\end{array}$ & $\begin{array}{c}14 \\
300 \text { th.u. }\end{array}$ & $\begin{array}{r}58 \\
84 \\
118 \\
13\end{array}$ & $\begin{array}{c}109 \\
+ \\
0 \\
0\end{array}$ & $\begin{array}{l}2.7 \\
3.2\end{array}$ & $\begin{array}{l}4.9 \\
7.1\end{array}$ & $\begin{array}{c}0 \\
10^{7} \\
10^{6}\end{array}$ & $\begin{array}{c}0 \\
10^{7} \\
10^{5}\end{array}$ & $\begin{array}{c}0.36 \\
6.3 \\
18.5\end{array}$ & & $\begin{array}{r}0 \\
0 \\
32 \\
16\end{array}$ & Died & 20 \\
\hline 7 & M 40 & Serum & $\begin{array}{l}65 \\
84\end{array}$ & $\begin{array}{r}30 \\
5\end{array}$ & $\begin{array}{c}5 \\
120 \text { th.u. }\end{array}$ & $\begin{array}{r}65 \\
84 \\
106 \\
9\end{array}$ & $\begin{array}{l}0 \\
0\end{array}$ & 4.0 & 5.2 & $\begin{array}{l}10^{2} \\
10^{5} \\
10^{4}\end{array}$ & $\begin{array}{l}10^{3} \\
10^{4} \\
10^{4}\end{array}$ & \begin{tabular}{|l}
0 \\
0.14 \\
27.5
\end{tabular} & & $\begin{array}{l}0 \\
0 \\
8 \\
4\end{array}$ & Crisis & 96 \\
\hline 8 & M 39 & $\begin{array}{c}\text { S.P. } \\
\text { Serum }\end{array}$ & $\begin{array}{l}123 \\
166\end{array}$ & $\begin{array}{r}48 \\
7\end{array}$ & $\begin{array}{c}15 \\
170 \text { th.u. }\end{array}$ & $\begin{array}{l}112 \\
121 \\
166\end{array}$ & $\begin{array}{r}21 \\
1 \\
0\end{array}$ & 3.2 & 5.8 & $\begin{array}{l}10^{2} \\
10^{2} \\
10^{5}\end{array}$ & $\begin{array}{l}10^{2} \\
10^{2} \\
10^{6}\end{array}$ & $\begin{array}{l}0 \\
0.1 \\
1.1\end{array}$ & $\begin{array}{l}10 \\
10 \\
10^{5}\end{array}$ & $\begin{array}{l}0 \\
0 \\
0\end{array}$ & Died & 174 \\
\hline
\end{tabular}

Explanation of tables: S.P. = sulfapyridine. Tr. = trace. Serum: Th.u. = thousand units.

Day of disease and day of termination: Wherever relevant, the number of hours after onset is indicated. Italics indicate actual day of the disease.

Blood culture: $+=$ growth of homologous type pneumococcus; 0 = no growth; numbers indicate colonies per cc. of blood in agar pour plates.

Growth inhibition: Numbers represent largest inoculum which failed to show color change.

Pneumococci killed: Inoculum which yielded no growth in agar pour plates after 48 hours' incubation in blood.

Protection: Largest number of lethal doses protected by $0.2 \mathrm{cc}$. of serum; $10^{6} \times 4,10^{6} \times 10$, etc. indicates protection against $10^{6}$ lethal doses by $0.2 \mathrm{cc}$. of $1: 4,1: 10$ dilution of the original serum, respectively.

Agglutinins: The greatest final dilution of serum showing floccular agglutination.

Crisis: Time when temperature first dropped below $100^{\circ} \mathrm{F}$. with improvement in symptoms.

Lysis: Same, with fever persisting. 
in which the data are inadequate are excluded from the tables but the individual observations are included in the figures. The results of tests made with blood obtained after serum therapy are excluded from the figures.

In Table I are listed the data on 8 patients who were studied with pneumococcidal and phagocytic tests. These cases were chosen to illustrate both the variations occurring in the immune state before treatment as well as to give some indication of the variety of responses noted to treatment with sulfapyridine alone or to the administration of

TABLE II

Results of homologous protection and agglutination tests in additional cases of pneumococcus Type I pneumonia treated with sulfapyridine

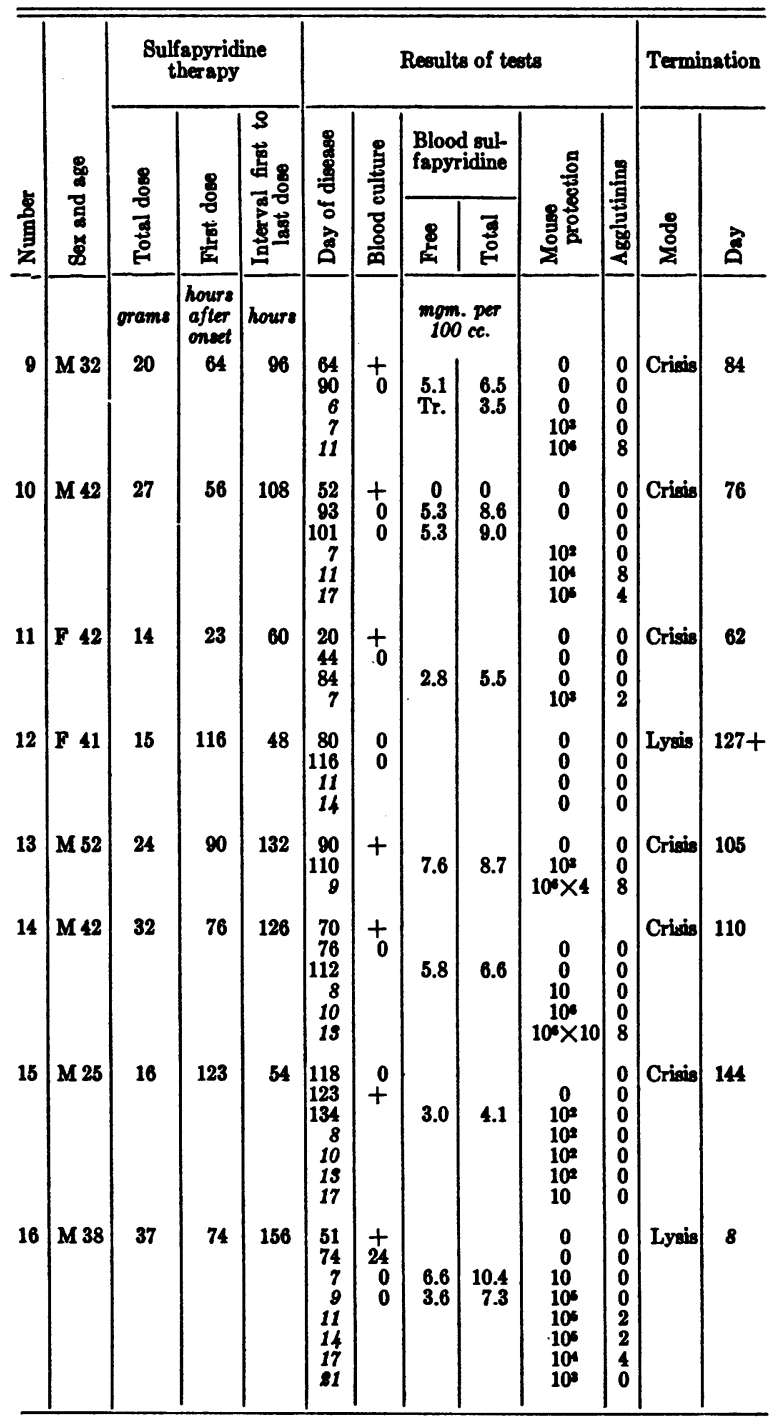

TABLE II-Continued

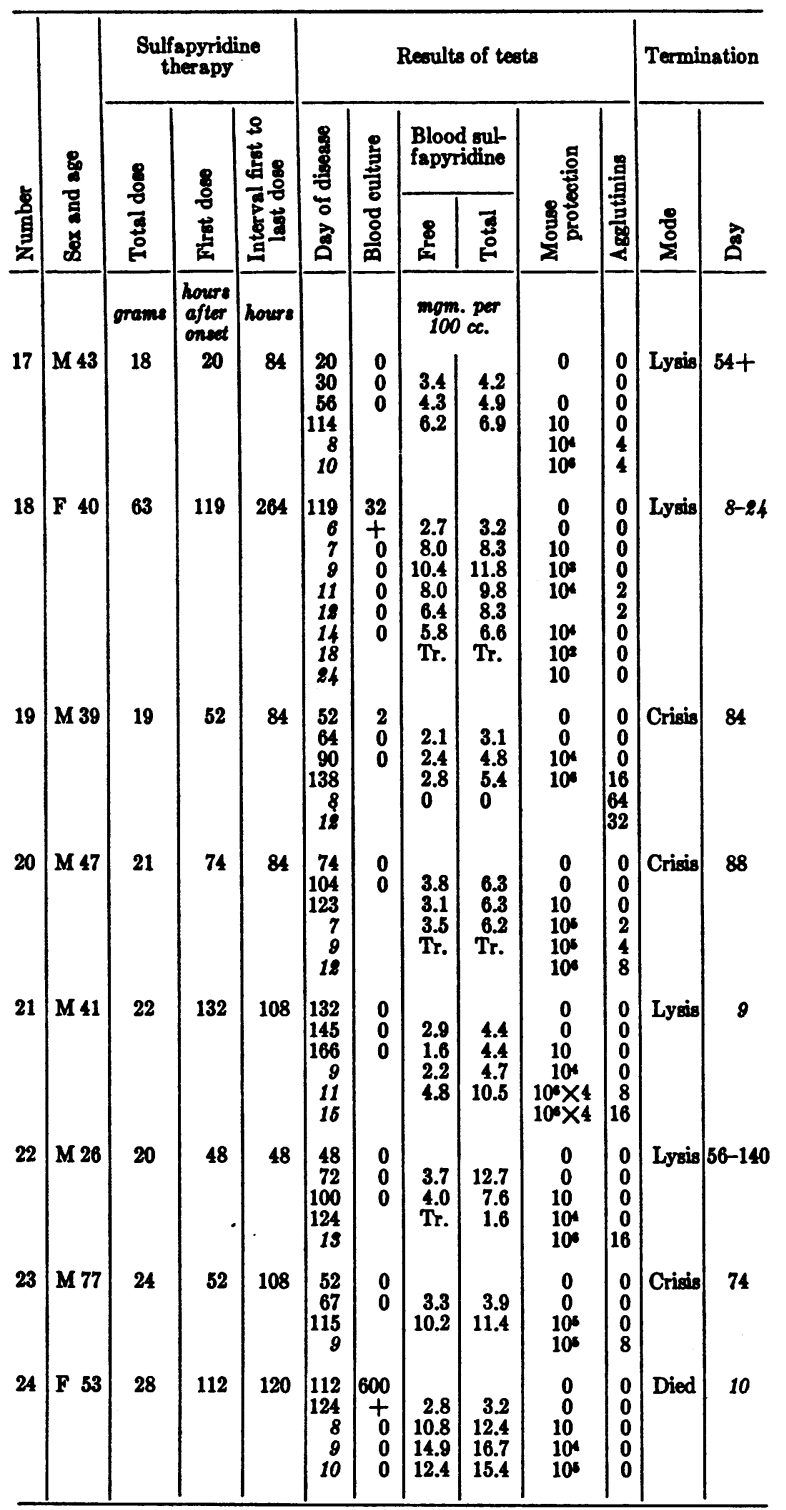

the combination of sulfapyridine and serum. Some of the patients had pneumococcal activity in their blood before treatment. In some instances (Numbers 4 and 8 ) mouse protective antibody was demonstrated before the institution of therapy. In the control tests done on the bloods taken before treatment, when inhibition of growth or killing took place, both occurred to the same degree and this was irrespective of the presence of protective antibodies or agglutinins. This parallelism between growth inhibition and killing was also evident when other antibodies (protec- 


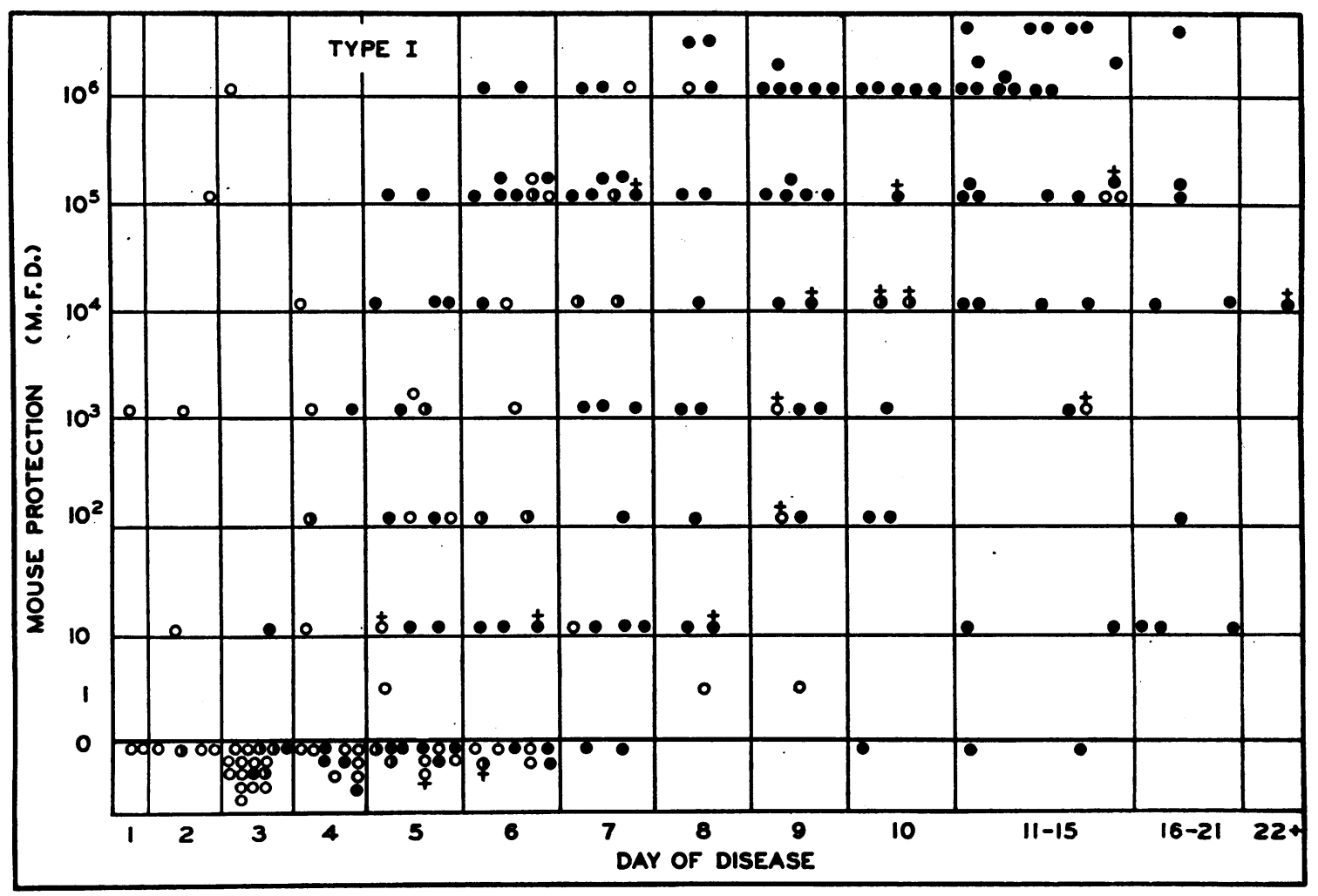

Fig. 1

See Figure 4 for explanation

tion, agglutinins, opsonins) were acquired either spontaneously or after the administration of specific serums. In the bloods taken following sulfapyridine therapy, the extent of inhibition and of killing was not always parallel in the absence of other antibodies. This lack of parallelism is even more evident with respect to growth inhibition after 24 hours, as will be seen later. While growth inhibition and killing occurred following sulfapyridine therapy in the absence of other antibodies, these activities occurred to a considerably greater extent in the presence of the other antibodies.

Four patients who were treated with the combination of sulfapyridine and serum are included in Table I. One of these (Number 5) had a severe infection with a massive bacteremia; serum and sulfapyridine were started almost simultaneously, a balance of antibodies was rapidly established and maintained and the patient recovered. In the other 3 patients specific serum was given at varying intervals after therapy with sulfapy- ridine was started because the clinical response was considered inadequate. Two of these $3 \mathrm{pa}$ tients died. At the time serum was started in one of these cases (Number 6) the concentration of sulfapyridine in the blood was low; bacteremia was still present and extension of the pulmonary lesion had occurred. Pneumococcidal tests were not done immediately before the administration of serum in this case but a high titer of antibodies was established and maintained after serum was given, and the drug had to be omitted because of excessive vomiting. The patient developed empyema and died at the end of the third week of illness with a complicating hemolytic streptococcus septicemia. In the other fatal case (Number 8 ) a rapid downhill course continued after sulfapyridine was given. Serum treatment was undertaken when the patient was in extremis and death occurred shortly thereafter. In spite of the unfavorable course in this case it was found that protective antibodies and some opsonins had developed at the time serum treatment was insti- 


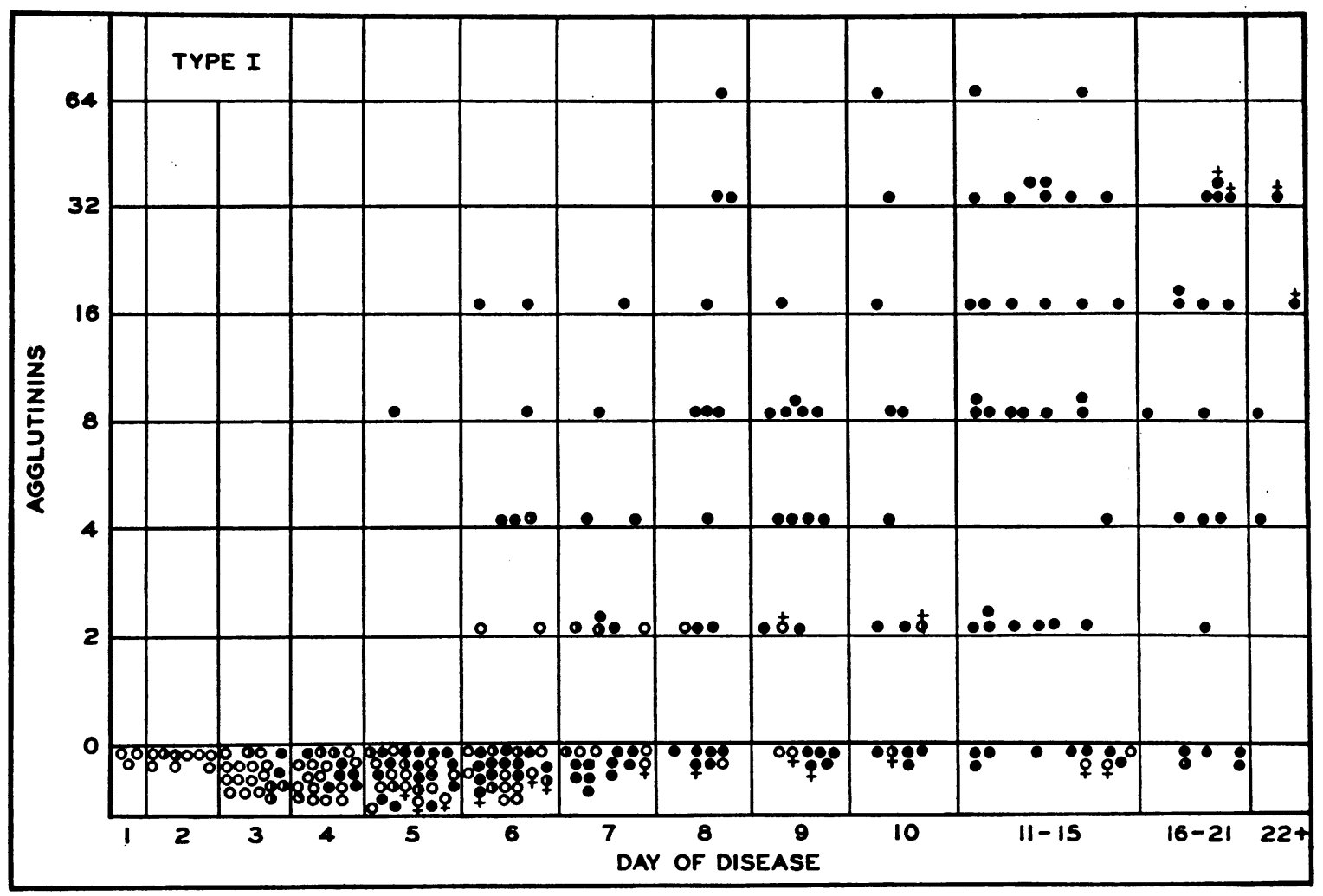

Fig. 2

See Figure 4 for explanation

tuted. The blood of the fourth patient (Number 7) had pneumococcidal power before treatment and this increased after sulfapyridine and before serum was given. Crisis occurred 12 hours after the first dose of serum and 31 hours after the first dose of sulfapyridine. The relation of pneumococcidal activity to the presence of agglutinins and protective antibody was the same regardless of whether the latter antibodies were injected or actively acquired.

The results of tests for mouse protection and agglutinins in 16 other patients are given in Table II. Here it is seen more clearly that these antibodies do not appear coincident with sulfapyridine-induced crises. This is particularly true with respect to the agglutinins. Patients in whom mouse protection was present before treatment are excluded from this table, but the results of such tests are given in the figures.

A study of Figures 1 and 2 indicates that mouse protective antibodies were infrequent before the fifth day of the disease and agglutinins rarely oc- curred before the sixth or seventh day. When such antibodies were present early they occurred with similar frequency in bloods obtained before or after treatment. For example, on the sixth day (Figure 1), 7 of 12 patients tested either before or within 24 hours of the beginning of treatment had protective antibodies. On this same day 11 of 14 patients who had already received therapy for more than 24 hours had mouse protective antibodies All of the tests done on the seventh day or later, but before treatment, showed the presence of some protective antibodies. In most of the patients in whom treatment was begun after the seventh day agglutinins were not found in the blood before treatment. These were severe cases and most of them died. Recovery was associated with the development of protective antibody in each instance, except in Case 12. Agglutinins were not demonstrated in this and in 2 other cases (15 and 24 ). In the latter there was a massive bacteremia before treatment, empyema developed, and death occurred after the blood 
TABLE III

Patients with pneumococcus Type II preumonia treated with sulfapyridine

\begin{tabular}{|c|c|c|c|c|c|c|c|c|c|c|c|c|}
\hline \multirow[b]{3}{*}{$\begin{array}{l}\text { 兽 } \\
\text { 尊 }\end{array}$} & \multirow{3}{*}{ 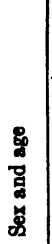 } & \multicolumn{3}{|c|}{$\begin{array}{l}\text { Sulfapyridine } \\
\text { therapy }\end{array}$} & \multicolumn{6}{|c|}{ Results of tests } & \multicolumn{2}{|c|}{$\underset{\text { tion }}{\text { Termina- }}$} \\
\hline & & \multirow{2}{*}{$\begin{array}{l}\mathbf{8} \\
\stackrel{8}{8} \\
\text { 曾 }\end{array}$} & \multirow{2}{*}{ 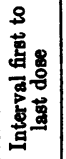 } & \multirow[b]{2}{*}{$\begin{array}{l}\overrightarrow{\mathrm{Z}} \\
\text { 首 }\end{array}$} & \multirow{2}{*}{ 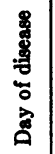 } & \multirow{2}{*}{ 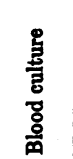 } & \multicolumn{2}{|c|}{$\begin{array}{l}\text { Blood sut- } \\
\text { fapyridine }\end{array}$} & \multirow{2}{*}{ 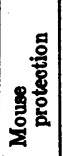 } & \multirow{2}{*}{ 睪 } & \multirow[b]{2}{*}{ छั } & \multirow[b]{2}{*}{ 密 } \\
\hline & & & & & & & 8 & 丞 & & & & \\
\hline & & $\begin{array}{l}\text { hours } \\
\text { after } \\
\text { onset }\end{array}$ & hours & grams & & & $\operatorname{mom}_{100}$ & $\begin{array}{l}\text { per } \\
\text { ce. }\end{array}$ & & & & \\
\hline 1 & M 38 & 87 & 7 & 43 & $\begin{array}{r}86 \\
101 \\
125 \\
177\end{array}$ & $+_{0}^{33}$ & $\begin{array}{l}3.8 \\
2.3 \\
2.9\end{array}$ & $\begin{array}{l}5.9 \\
4.3 \\
5.3\end{array}$ & $\begin{array}{c}0 \\
0 \\
10 \\
106\end{array}$ & $\begin{array}{l}0 \\
0 \\
0 \\
32\end{array}$ & Crisis & 167 \\
\hline 2 & F 35 & 98 & 84 & 16 & $\begin{array}{r}98 \\
138 \\
164 \\
13\end{array}$ & $\begin{array}{l}0 \\
0\end{array}$ & $\begin{array}{l}9.1 \\
7.7\end{array}$ & $\begin{array}{l}14.2 \\
13.5\end{array}$ & $\begin{array}{c}0 \\
10^{3} \\
10^{5}\end{array}$ & $\begin{array}{l}0 \\
4 \\
8 \\
8\end{array}$ & Criais & 136 \\
\hline 3 & M 62 & 87 & 108 & 25 & $\begin{array}{c}87 \\
122 \\
171 \\
14 \\
28+\end{array}$ & 0 & $\begin{array}{l}9.3 \\
6.3\end{array}$ & $\begin{array}{c}10.4 \\
8.8\end{array}$ & $\begin{array}{l}0 \\
0 \\
0 \\
0 \\
0\end{array}$ & $\begin{array}{l}0 \\
0 \\
0 \\
0 \\
0\end{array}$ & Crisis & 117 \\
\hline 4 & M 33 & 40 & 132 & 37 & $\begin{array}{r}22 \\
40 \\
98 \\
9\end{array}$ & $\begin{array}{l}0 \\
0\end{array}$ & 10.7 & 11.6 & $\begin{array}{l}10^{4} \\
10^{6}+\end{array}$ & $\begin{array}{l}16 \\
16 \\
16 \\
16\end{array}$ & Crisis & 68 \\
\hline 5 & F 43 & 122 & 14 & 7 & $\begin{array}{l}112 \\
138\end{array}$ & $\begin{array}{l}\mathbf{0} \\
\mathbf{0}\end{array}$ & 3.9 & 4.0 & $\begin{array}{l}10^{2} \\
10^{2}\end{array}$ & 4 & Lysis & $8-10$ \\
\hline 6 & M 52 & 98 & 108 & 28 & $\begin{array}{r}98 \\
137 \\
170^{\circ} \\
17\end{array}$ & $\begin{array}{l}\mathbf{0} \\
\mathbf{0} \\
\mathbf{0}\end{array}$ & $\begin{array}{l}2.0 \\
1.5\end{array}$ & $\begin{array}{l}4.7 \\
3.6\end{array}$ & $\begin{array}{l}10^{2} \\
10^{5}\end{array}$ & $\begin{array}{r}0 \\
16 \\
32 \\
32\end{array}$ & Crisis & 180 \\
\hline 7 & M 28 & 106 & 108 & 29 & $\begin{array}{c}106 \\
118 \ddagger \\
145 \\
10\end{array}$ & $\begin{array}{r}32 \\
31 \\
0\end{array}$ & $\begin{array}{l}3.2 \\
4.5 \\
1.8\end{array}$ & $\begin{array}{l}4.8 \\
9.5 \\
4.3\end{array}$ & $\begin{array}{l}0 \\
0\end{array}$ & $\begin{array}{r}0 \\
0 \\
8 \\
32\end{array}$ & Crisis & 124 \\
\hline 8 & M 44 & 124 & 30 & 10 & $\begin{array}{l}1238 \\
150 \\
158\end{array}$ & $\begin{array}{r}15,000 \\
2 \\
2\end{array}$ & $\begin{array}{l}2.0 \\
2.2\end{array}$ & $\begin{array}{l}2.1 \\
2.5\end{array}$ & & $\begin{array}{r}0 \\
32 \\
4\end{array}$ & Died & 162 \\
\hline
\end{tabular}

* Serum, 170,000 units, given in 4 hours after this blood was obtained.

† Readmitted 15 days later with pneumonia; blood culture positive for Friedlander bacillus; died the next day.

$\ddagger$ Serum, 120,000 units, given in 2 hours after this blood was obtained.

$\$$ Serum, 500,000 units, given over a period of 22 hours after this blood was taken. This blood showed no growth inhibition or pneumococcidal action and no phagocytosis. With sulfapyridine, $5.0 \mathrm{mgm}$. per $100 \mathrm{cc}$., it inhibited the free growth of $10^{7}$ pneumococci but caused no killing; with sulfapyridine, $10.0 \mathrm{mgm}$. per $100 \mathrm{cc}$., it inhibited the free growth of $10^{7}$ pneumococci and killed $10^{2}$ in 48 hours; with sulfapyridine, $5.0 \mathrm{mgm}$. per $100 \mathrm{cc}$., and $1: 250$ dilution of specific serum, the latter result was duplicated but there was opsonization in addition (index 4.7).

stream had been rendered bacteria-free and protective antibodies had appeared.

In a number of serums in which protection was demonstrated against $1,000,000$ fatal doses, further titrations were carried out with this number of organisms, using serial dilutions of the serum. In one instance (Number 14), each of 2 mice was protected by $0.2 \mathrm{cc}$. of a $1: 10$ dilution of serum and in 2 patients (Numbers 13 and 21) duplicate mice were protected against this inoculum by 0.2 cc. of a 1:4 dilution of serum. These titers are equivalent, respectively, to 50 and 20 units of protective antibody per cc. of serum. Such titers were not reached until the ninth day of the disease or later.

Type II Cases. The results of protection and agglutination tests in 8 patients with Type II pneumococcic pneumonia, including 3 who received serum in addition, are shown in Table III. Three of these patients had mouse protective antibodies before treatment was begun and this protective antibody was associated with agglutinins in 2 of the latter cases. In Case 4 a high titer of antibody was present at the end of the first day of illness. In this patient the onset of the disease occurred in the hospital and followed the occurrence of pulmonary infarction. In Case 3, recovery occurred without the development of demonstrable protective antibodies or agglutinins. Two of the patients received serum after having been treated for varying periods with sulfapyridine, and crisis occurred 6 to 12 hours after the first injection of the antibody. In 1 of these patients the extent of bacteremia had not been influenced by the sulfapyridine therapy during a 12 -hour period before serum was given. In the third serum recipient, treatment with the drug and antibody was started at about the same time. In this patient there was an overwhelming bacteremia and the patient died.

The results of the protection and agglutination tests done in the serums of patients with Type II pneumonia, except for those done after serum treatment, are shown graphically in Figures 3 and 4 , respectively. The number of cases, particularly those in whom treatment was begun early in the disease, are too few to warrant conclusions. However, it is seen that except in 1 case (Number 4) protection and agglutinins occurred in every instance on the fifth day or later.

Bactericidal and opsonic tests were not done regularly in Type II cases. With this type, at least with our stock strain, high titers of these antibodies were found with great regularity before treatment, except in some cases with severe bacteremia. Case 8 was such a bacteremic case. The results of in vitro tests with blood taken in this 


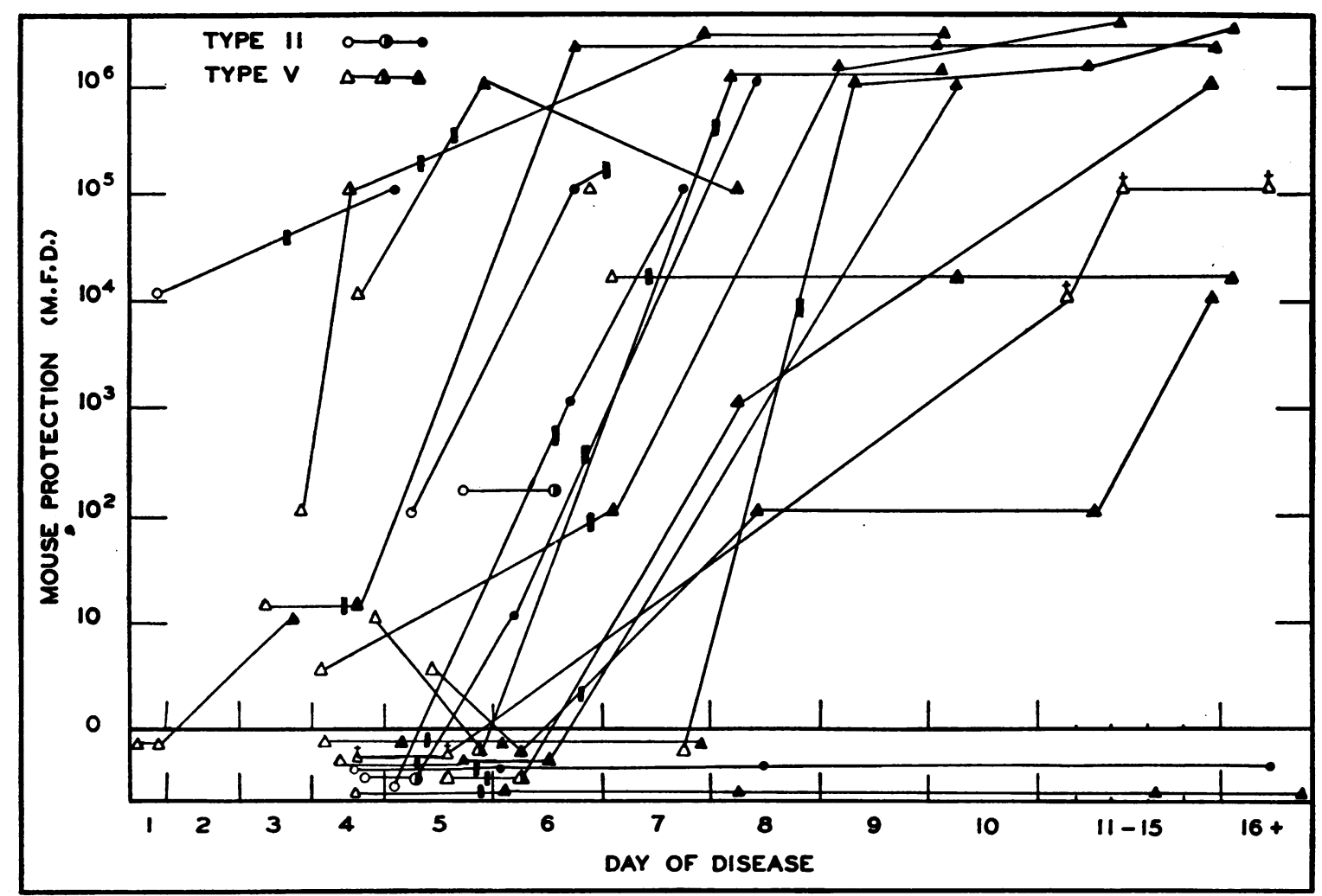

Fig. 3

See Figure 4 for explanation

case before treatment are noted in the table. These results may be interpreted as indicating that large amounts of antigen were neutralized in the blood temporarily by the addition of serum. This probability is further suggested by the drop in the agglutinin titer during the 8 hours between the 2 tests done after treatment. The preliminary serum showed a very dense precipitate when homologous antiserum was added-even with high dilutions of both the patient's serum and the specific Type II antiserum. Studies similar to the ones presented here have in the past been carried out on patients treated without sulfapyridine and have been previously reported $(2,3,4)$.

Type $V$ Cases. In Table IV are listed the results in 6 patients in whose blood bactericidal and opsonic tests were carried out. These included 3 patients with various titers of mouse protective antibody in serum obtained before treatment. This protection was associated in each instance with moderate to high bactericidal titers. The 3 patients whose serum lacked mouse protection be- fore treatment also had no appreciable pneumococcidal activity in the blood at this time. Protection was present in some instances early in the disease without high titers of opsonins (Cases 4, 5). In Case 1, neither protection nor agglutinins developed during the period of observation. At the beginning of the seventh day, however, this patient had good pneumococcidal activity and opsonins in his blood in the absence of circulating sulfapyridine. Such action was not demonstrable in the control blood taken before treatment.

Of 8 other Type V Cases which are shown in Table $\mathrm{V}$, the serum of 2 had protection against 1,000 or more fatal doses and in 1 there was protection against 10 fatal doses before treatment. Protective antibody in all the cases developed or increased on the sixth day or later and in every instance this occurred after crisis (Figure 3 ). Agglutinins usually appeared or increased after the sixth day (Figure 4).

Serum treatment supplemented sulfapyridine in 3 of the 14 cases shown in the tables. In Case 6 


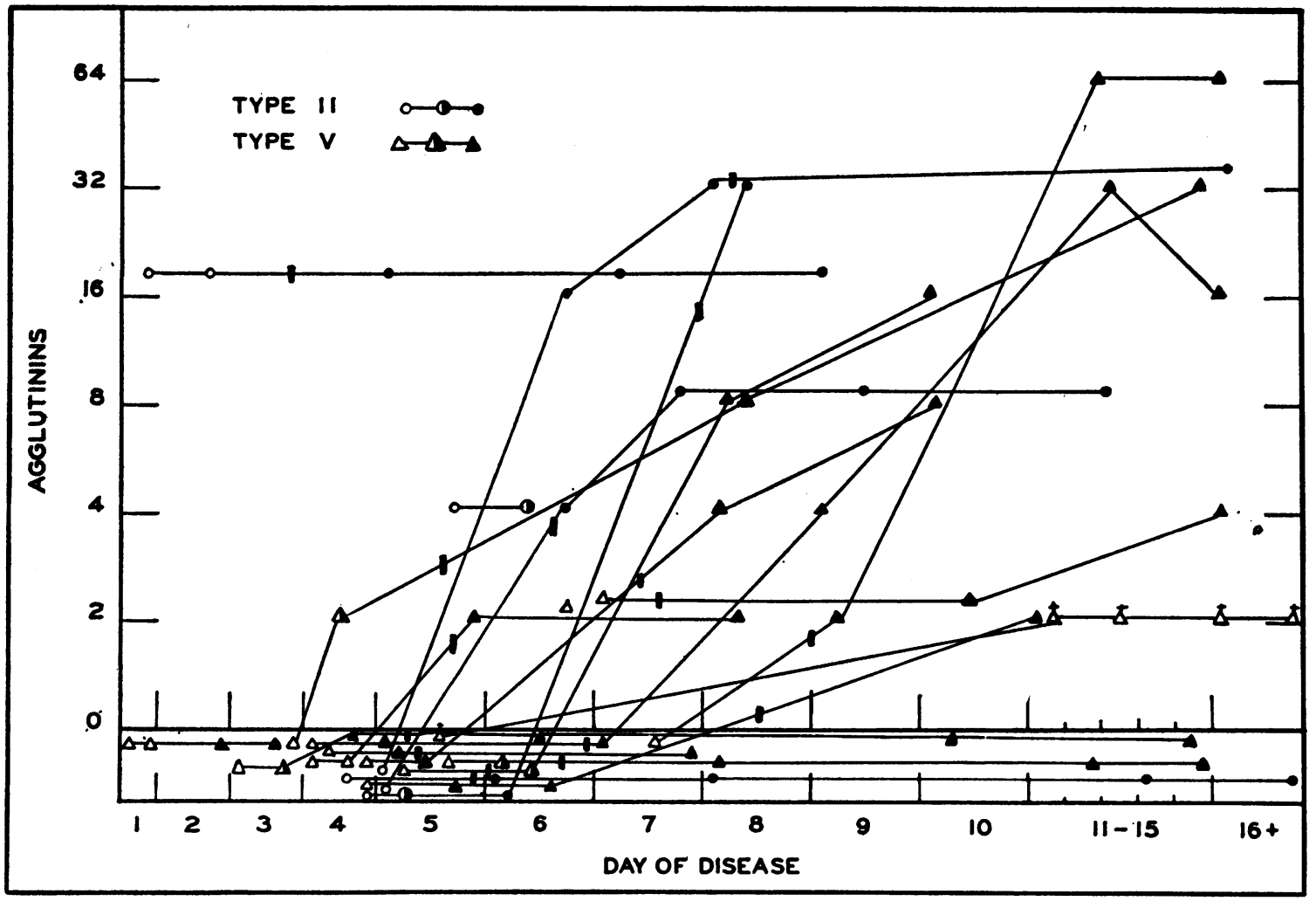

FIG. 4

EXPLANATION OF THE FIGURES

In Figures 1 to 4 open circles or triangles represent tests done before any sulfapyridine treatment was given, solid ones represent observations made more than 24 hours after the first dose of sulfapyridine and the ones half open and half solid represent observations made during the first 24 hours of treatment.

The solid lines serve to connect the tests made in individual patients. These lines are omitted for the sake of clarity from the charts of the Type I cases. The solid bar indicates the time of crisis.

Observations made after serum treatment are omitted.

$+=$ fatal case.

the patient showed less fever following sulfapyridine therapy. The drug was not well tolerated and the patient again appeared ill for about 36 hours after drug was discontinued. He was then given serum and became afebrile and symptomfree within 8 hours after the first injection. The other 2 cases appeared to be severely ill when treatment was begun and both serum and drug were started about the same time. Neither of these 2 patients had blood stream invasion before treatment; indeed, one had a good titer of antibodies at the time.

More detailed titrations of the amount of protective antibody present after crisis were made in the serum of 4 patients treated with sulfapyridine alone and, for comparison, in 2 other patients shortly after specific serum treatment. Only bloods in which 0.2 of a cc. of serum protected against $1,000,000$ fatal doses in preliminary tests were chosen for these more detailed titrations. In the 2 patients treated with specific serum (Numbers 6,14) the titrations showed 125 and 250 units per cc. of blood 16 and 18 hours, respectively, after the first injection of serum. Each of the 4 non-serum treated cases had 20 units or more. In Case 7, the titer rose from 20 to 125 units and in Case 10 from 50 to 250 units after the ninth and twelfth days respectively.

Previous studies on the antibody response of patients with Type $\mathrm{V}$ pneumonia treated without 
TABLE IV

Immunological tests in patients with pneumococcus Type $V$ and Type VIII pneumonia treated with sulfapyridine alone or with specific serum

\begin{tabular}{|c|c|c|c|c|c|c|c|c|c|c|c|c|c|c|c|c|}
\hline \multirow{3}{*}{ 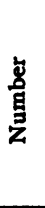 } & \multirow{3}{*}{$\begin{array}{l}\text { Sex } \\
\text { and } \\
\text { age }\end{array}$} & \multirow{3}{*}{ Therapy } & \multirow{3}{*}{$\begin{array}{l}\text { First } \\
\text { dose }\end{array}$} & \multirow{3}{*}{$\begin{array}{l}\text { Inter- } \\
\text { val } \\
\text { first to } \\
\text { last } \\
\text { dose }\end{array}$} & \multirow{3}{*}{ Amount } & \multicolumn{9}{|c|}{ Results of tests } & \multicolumn{2}{|c|}{ Termination } \\
\hline & & & & & & \multirow{2}{*}{$\begin{array}{c}\text { Day } \\
\text { of } \\
\text { dis- } \\
\text { ease }\end{array}$} & \multirow{2}{*}{$\begin{array}{c}\text { Blood } \\
\text { cul- } \\
\text { ture }\end{array}$} & \multicolumn{2}{|c|}{$\begin{array}{l}\text { Blood sulfa- } \\
\text { pyridine }\end{array}$} & \multirow{2}{*}{$\begin{array}{c}\text { Growth } \\
\text { inhibi- } \\
\text { tion }\end{array}$} & \multirow{2}{*}{$\left|\begin{array}{c}\text { Pneu- } \\
\text { mo- } \\
\text { coci } \\
\text { lilled }\end{array}\right|$} & \multirow{2}{*}{$\begin{array}{c}\text { Op- } \\
\text { sonic } \\
\text { index }\end{array}$} & \multirow{2}{*}{$\begin{array}{l}\text { Mouse } \\
\text { protec- } \\
\text { tion }\end{array}$} & \multirow{2}{*}{$\begin{array}{l}\text { Agglu- } \\
\text { tinins }\end{array}$} & \multirow{2}{*}{ Mode } & \multirow{2}{*}{ Day } \\
\hline & & & & & & & & Free & Total & & & & & & & \\
\hline & & & $\begin{array}{l}\text { hours } \\
\text { after } \\
\text { onset }\end{array}$ & hours & grams & & & \multicolumn{2}{|c|}{ mgm. per $100 \mathrm{cc}$. } & $\begin{array}{c}48 \\
\text { hours }\end{array}$ & & & & & & \\
\hline
\end{tabular}

TYPE $\mathbf{V}$ CASES

\begin{tabular}{|c|c|c|c|c|c|c|c|c|c|c|c|c|c|c|c|c|}
\hline $1^{*}$ & M 25 & S.P.† & 77 & 60 & 18 & $\begin{array}{r}77 \\
100 \\
121 \\
168\end{array}$ & $\begin{array}{l}0 \\
0\end{array}$ & $\begin{array}{l}5.4 \\
4.6 \\
0\end{array}$ & $\begin{array}{l}6.9 \\
7.9 \\
0\end{array}$ & $\begin{array}{c}0 \\
10^{5} \\
10^{6} \\
10^{5}\end{array}$ & $\begin{array}{c}0 \\
10^{5} \\
10^{6} \\
10^{5}\end{array}$ & $\begin{array}{l}0.14 \\
0 \\
0.22 \\
8.4\end{array}$ & $\begin{array}{l}0 \\
0 \\
0\end{array}$ & $\begin{array}{l}0 \\
0 \\
0 \\
0\end{array}$ & Crisis & 106 \\
\hline 2 & M 44 & S.P. & 74 & 156 & 37 & $\begin{array}{r}74 \\
111 \\
135 \\
11\end{array}$ & $\begin{array}{l}0 \\
0 \\
0\end{array}$ & 3.5 & 5.6 & $\begin{array}{l}10 \\
10^{6} \\
10^{4}\end{array}$ & $\begin{array}{l}10 \\
10^{4} \\
10^{3}\end{array}$ & $\begin{array}{c}0.74 \\
0 \\
36.4\end{array}$ & $\begin{array}{c}0 \\
0 \\
0 \\
10^{6}\end{array}$ & $\begin{array}{l}0 \\
0 \\
0 \\
2\end{array}$ & Lysis & $5-8$ \\
\hline 3 & M 53 & S.P. & 96 & 78 & 20 & $\begin{array}{r}96 \\
107 \\
8 \\
10\end{array}$ & 0 & $\begin{array}{l}4.5 \\
\text { Tr. }\end{array}$ & $\begin{array}{l}4.7 \\
\text { Tr. }\end{array}$ & $\begin{array}{l}10^{6} \\
10^{7}\end{array}$ & $\begin{array}{l}10^{6} \\
10^{7}\end{array}$ & $\begin{array}{l}1.6 \\
1.3\end{array}$ & $\begin{array}{c}10 \\
0 \\
10^{6} \\
10^{6}\end{array}$ & $\begin{array}{l}0 \\
0 \\
4 \\
8\end{array}$ & Crisis & 7 \\
\hline 4 & F 32 & S.P. & 86 & 84 & 19 & $\begin{array}{r}86 \\
96 \\
120\end{array}$ & $\begin{array}{l}\mathbf{0} \\
\mathbf{0} \\
\mathbf{0}\end{array}$ & $\begin{array}{l}5.3 \\
5.6\end{array}$ & $\begin{array}{l}5.7 \\
7.2\end{array}$ & $\begin{array}{l}10^{3} \\
10^{6} \\
10^{4}\end{array}$ & $\begin{array}{l}10^{3} \\
10^{3} \\
10^{3}\end{array}$ & $\begin{array}{l}0.96 \\
0.60 \\
0.8\end{array}$ & $\begin{array}{l}10^{4} \\
10^{6}\end{array}$ & $\begin{array}{l}0 \\
0 \\
2\end{array}$ & Crisis & 115 \\
\hline 5 & M 52 & $\begin{array}{c}\text { S.P. } \\
\text { Serum }\end{array}$ & $\begin{array}{l}140 \\
146\end{array}$ & $\begin{array}{l}96 \\
11\end{array}$ & $\begin{array}{c}31 \\
320 \text { th.u. } \delta\end{array}$ & $\begin{array}{r}140 \\
146 \\
160 \\
13\end{array}$ & $\begin{array}{l}\mathbf{0} \\
\mathbf{0} \\
\mathbf{0}\end{array}$ & $\begin{array}{l}0 \\
1.3 \\
5.4 \\
0\end{array}$ & $\begin{array}{l}0 \\
3.3 \\
9.9 \\
0\end{array}$ & $\begin{array}{l}10^{4} \\
10^{6} \\
10^{6} \\
10^{6}\end{array}$ & $\begin{array}{l}10^{4} \\
10^{4} \\
10^{4} \\
10^{6}\end{array}$ & $\begin{array}{c}0.44 \\
2.5 \\
14.6 \\
7.3\end{array}$ & $\begin{array}{l}10^{5} \\
10^{6}\end{array}$ & $\begin{array}{r}2 \\
32 \\
16\end{array}$ & Lysis & $8-17$ \\
\hline 6 & M 66 & $\begin{array}{l}\text { S.P. } \\
\text { Serum }\end{array}$ & $\begin{array}{l}20 \\
72\end{array}$ & $\begin{array}{r}18 \\
4\end{array}$ & $\begin{array}{c}8 \\
160 \text { th.u. }\end{array}$ & $\begin{array}{l}20 \\
43 \\
65 \\
88 \\
10\end{array}$ & $\begin{array}{l}\mathbf{0} \\
\mathbf{0} \\
\mathbf{0}\end{array}$ & $\begin{array}{l}5.0 \\
\text { Tr. } \\
0\end{array}$ & $\begin{array}{l}9.5 \\
2.9 \\
\text { Tr. }\end{array}$ & $\begin{array}{c}0 \\
10^{5} \\
10^{5} \\
10^{4} \\
10^{5}\end{array}$ & $\begin{array}{c}0 \\
10^{5} \\
10^{5} \\
10^{4} \\
10^{5}\end{array}$ & $\begin{array}{c}1.5 \\
0.88 \\
0.70 \\
15.4 \\
+\end{array}$ & $\begin{array}{c}0 \\
0 \\
10 \\
10^{6} \times 25 \\
10^{6} \times 10\end{array}$ & $\begin{array}{r}0 \\
0 \\
0 \\
16 \\
8\end{array}$ & Lysis & $38-80$ \\
\hline
\end{tabular}

TYPE VIII CASES

\begin{tabular}{|c|c|c|c|c|c|c|c|c|c|c|c|c|c|c|c|c|}
\hline 1 & M 49 & S.P. & 62 & 84 & 16 & $\begin{array}{r}62 \\
81 \\
7 \\
11\end{array}$ & $\begin{array}{l}0 \\
0\end{array}$ & 6.7 & 8.3 & $\begin{array}{l}10^{2} \\
10^{5} \\
\\
10^{5}\end{array}$ & $\begin{array}{l}10^{3} \\
10^{5} \\
10^{4}\end{array}$ & $\begin{array}{l}0.90 \\
0 \\
1.9\end{array}$ & $\begin{array}{c}10 \\
0 \\
10^{2} \\
10^{2}\end{array}$ & $\begin{array}{l}0 \\
0 \\
0 \\
0\end{array}$ & Crisis & 72 \\
\hline 2 & M 33 & S.P. & 28 & 108 & 18 & $\begin{array}{r}28 \\
40 \\
92 \\
145 \\
9\end{array}$ & $\underset{0}{+}$ & $\begin{array}{l}4.7 \\
5.9\end{array}$ & $\begin{array}{l}5.4 \\
6.2\end{array}$ & $\begin{array}{l}10^{3} \\
10^{5} \\
\\
10^{6} \\
10^{5}\end{array}$ & $\begin{array}{l}10^{8} \\
10^{5} \\
10^{6} \\
10^{4}\end{array}$ & $\begin{array}{l}0.48 \\
0 \\
0.68 \\
1.2\end{array}$ & $\begin{array}{r}0 \\
0 \\
0 \\
10\end{array}$ & $\begin{array}{l}0 \\
0 \\
0 \\
0 \\
2\end{array}$ & Crisis & 31 \\
\hline
\end{tabular}

* Pn. III and V in sputum. No antibodies for Pn. III developed.

† S.P. = sulfapyridine.

† Sulfanilamide given in first 3 days of illness at home.

$\$$ th.u. = thousand units. 
TABLE V

Additional patients with preumococcus $T y$ pe $V$ pneumonia treated with sulfapyridine

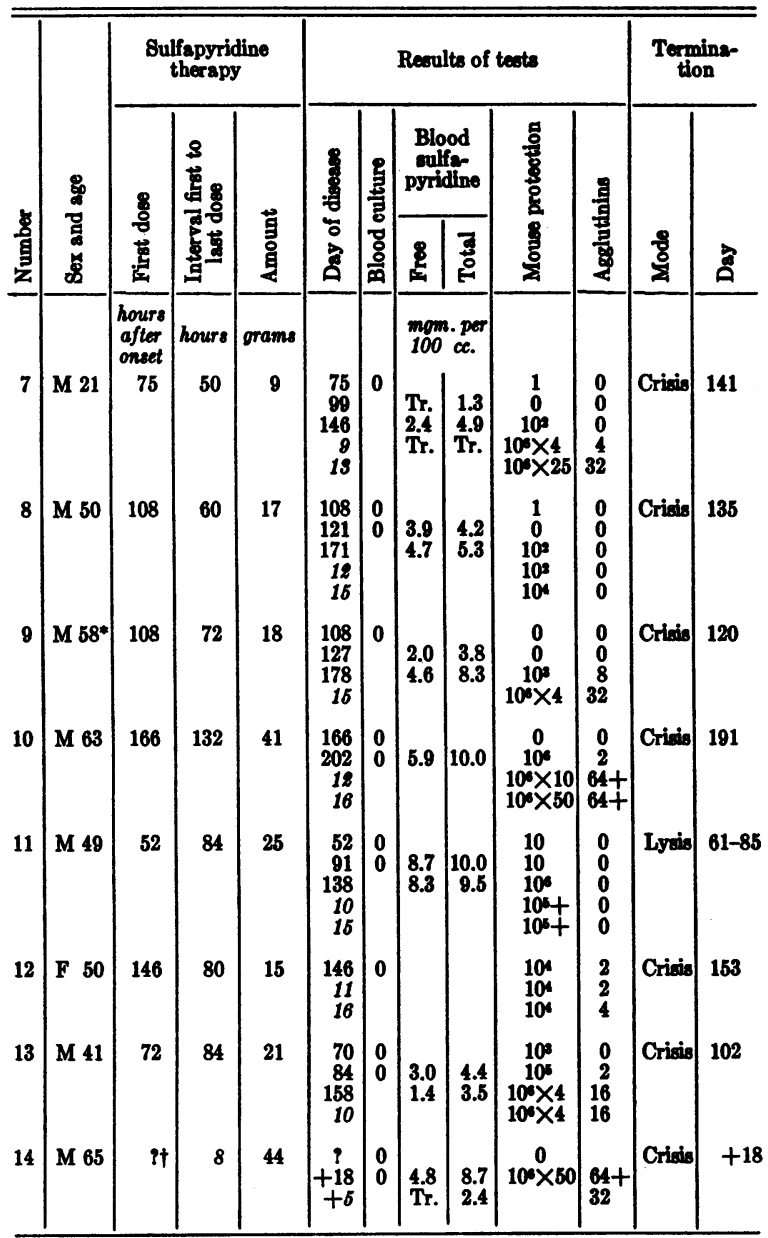

* Pn. XIII also found in sputum. All sera agglutinated Pn. XIII in $1: 4$ dilution.

† Serum treatment begun 3 hours later; 320,000 units given within 4 hours.

serums or active chemicals have been reported from this laboratory (4).

Type VII Cases. In this type as in the Type II Cases, pneumococcidal tests were not carried out because of the high titers regularly demonstrable before and during the course of treatment. Protective antibodies, as previously pointed out $(5,6)$, are also frequently present in high titers early in the course of pneumonia due to this type of pneumococcus. The same is not true, however, for homologous agglutinins. Most of the patients in whom blood taken before sulfapyridine treatment showed protective antibody were not followed further and are not shown in the table.

In Table VI are listed the results of protection and agglutination tests in 15 cases of Type VII pneumococcus pneumonia. Eight of these patients had protective antibodies in various titers in the early serum taken before treatment. In the 5 patients whose blood showed no protection before therapy, such antibodies appeared in appreciable titers only after the sixth day. This was after the time of crisis in each instance. Agglutinins appeared on the sixth day or earlier in only 2 of the 13 patients who did not receive serum and 1 of these 2 patients had protective antibody prior to treatment.

Serum treatment supplemented chemotherapy

TABLE VI

Patients with pneumococcus Type VII pneumonia treated with sulfapyridine

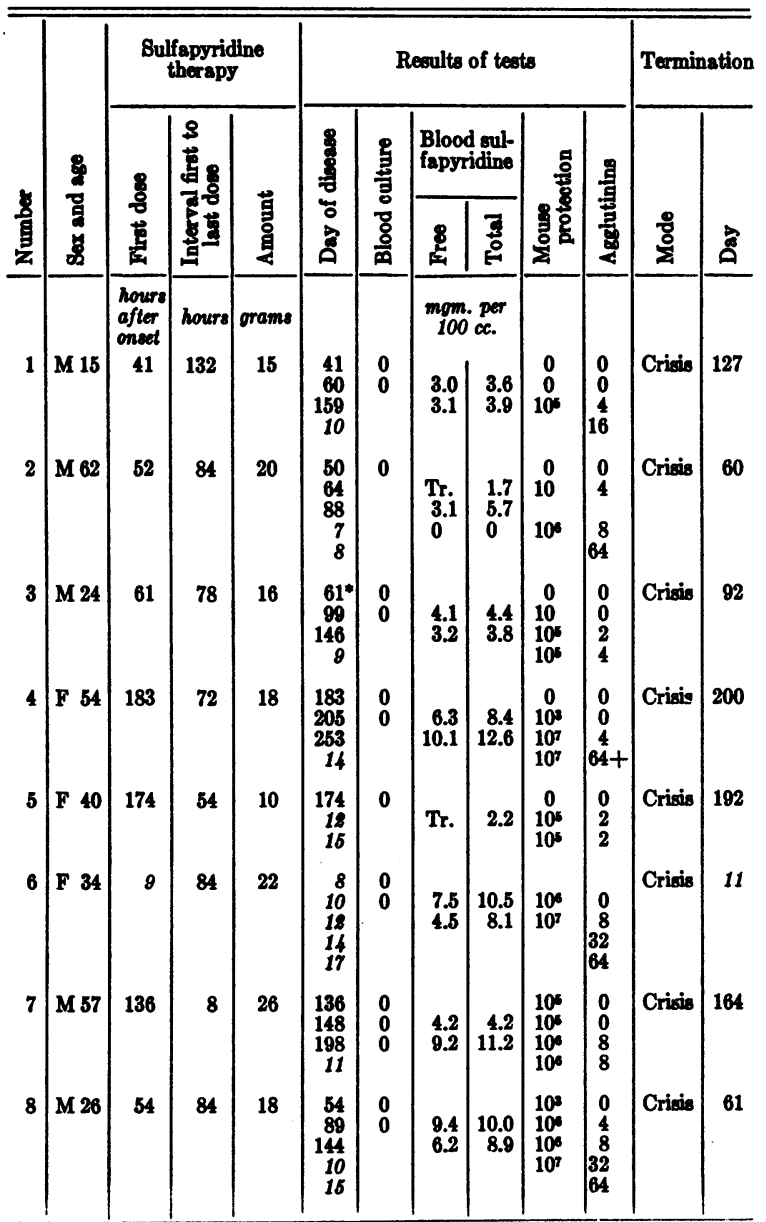


TABLE v1-Continued

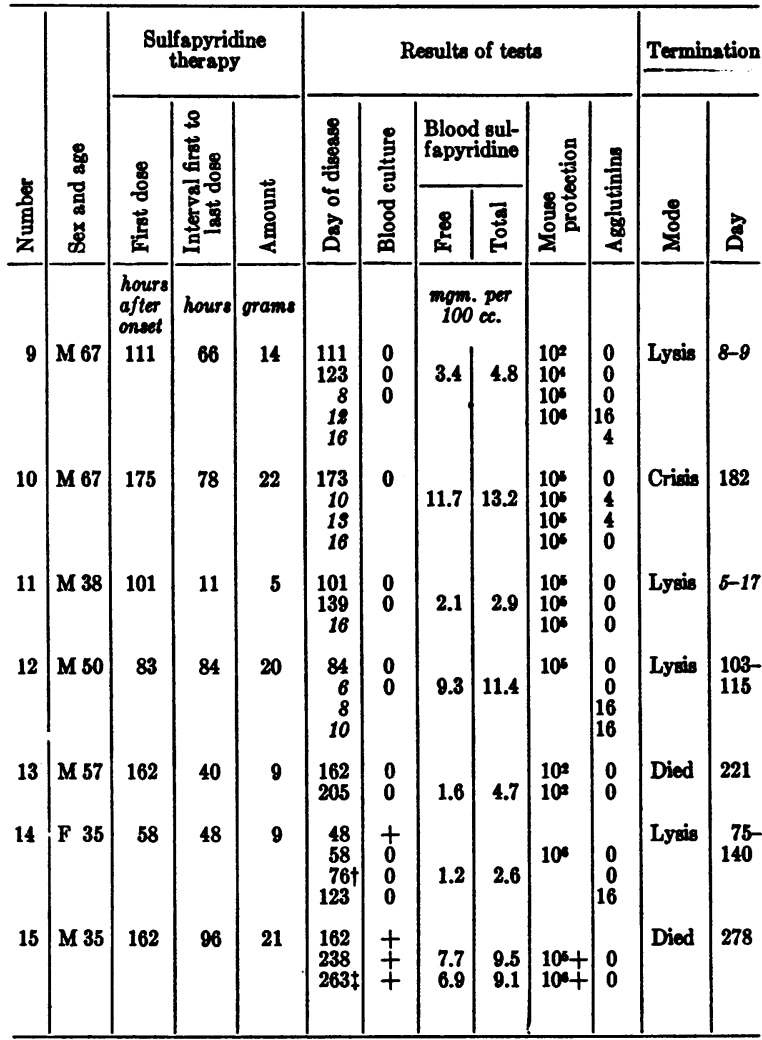

* Blood culture taken 7 hours before was positive.

$\dagger$ Serum treatment begun 4 hours later: 360,000 units given in 19 hours.

I Hematuria, leukocytosis $(55,000)$, and severe toxic symptoms after sulfapyridine. Serum treatment begun at this time, 100,000 units given in 2 hours. Transfused 2 days previously.

in 2 of the cases. In Case 14 bacteremia was present but it had already ended before treatment with the drug was begun. Serum therapy was started at a time when the patient's temperature had already dropped; the blood had remained sterile but the symptoms and other signs of activity and progressive pneumonia were still present. Recovery was slow even after serum administration. In Case 15, 21 grams of sulfapyridine had been given in the course of 4 days without affecting the bacteremia or the pneumonia. Severe toxic symptoms from the drug, including hematuria and marked leukocytosis, developed. Serum treatment was finally undertaken but the patient died within a few hours after the first dose.

Type VIII Cases. The results of the antibody studies in 15 patients with pneumococcus Type
TABLE VII

Additional patients with pneumococcus Type VIII pneumonia treated with sulfapyridine

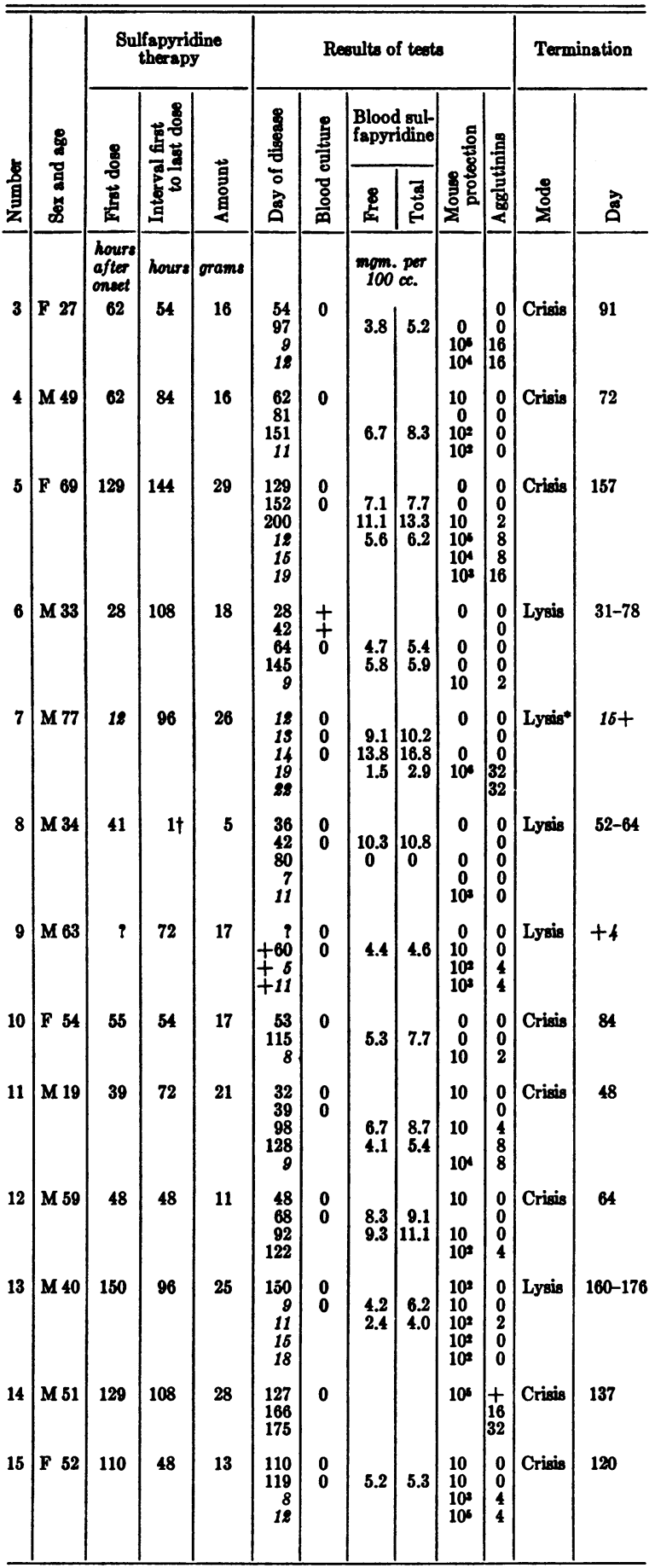

* Abscess of leg and suppurative otitis media. Marked excitement during treatment. Hematuria.

† Single dose of $\mathbf{5}$ grams of sulfapyridine in $\mathbf{5 0}$ per cent dextrose solution intravenously $(7)$. 
VIII pneumonia are shown in Tables IV and VII. Bactericidal tests were done before treatment in a number of cases but all of the bloods tested showed marked pneumococcidal properties at this time and further tests were not carried out in most instances. The results in 2 cases in which the tests were carried through after treatment are shown in Table IV. These results were essentially the same as in the cases of other types.

Mouse protective antibody was demonstrated before treatment in 7 cases. In 5 of these patients, however, the blood protected against only 10 lethal doses early in the disease and this titer either remained the same or was no longer demonstrable in a later test. In the 2 patients who showed protection against 100 and 10,000 fatal doses (Numbers 13,14 ) the earliest tests were done on the seventh and sixth days, respectively. Protection developed in all the other patients in various degrees and at the usual time. Agglu-

TABLE VIII

Patients with pneumococcus Type III pneumonia treated with sulfapyridine or with the combination of sulfapyridine and specific serum

\begin{tabular}{|c|c|c|c|c|c|c|c|c|c|c|c|c|c|c|c|c|}
\hline \multirow{3}{*}{$\underset{\text { ber }}{\text { Num- }}$} & \multirow{3}{*}{$\begin{array}{l}\text { Age } \\
\text { and } \\
\text { sex }\end{array}$} & \multirow{3}{*}{ Therapy } & \multirow{3}{*}{$\begin{array}{l}\text { First } \\
\text { dose }\end{array}$} & \multirow{3}{*}{$\begin{array}{l}\text { Inter- } \\
\text { val } \\
\text { first to } \\
\text { last } \\
\text { dose }\end{array}$} & \multirow{3}{*}{ Amount } & \multicolumn{9}{|c|}{ Results of tests } & \multicolumn{2}{|c|}{ Termination } \\
\hline & & & & & & \multirow{2}{*}{$\begin{array}{c}\text { Day } \\
\text { of } \\
\text { dis- } \\
\text { ease }\end{array}$} & \multirow{2}{*}{$\begin{array}{c}\text { Blood } \\
\text { cul- } \\
\text { ture }\end{array}$} & \multicolumn{2}{|c|}{$\begin{array}{l}\text { Blood sulfa- } \\
\text { pyridine }\end{array}$} & \multirow{2}{*}{$\begin{array}{l}\text { Growth } \\
\text { inhibi- } \\
\text { tion }\end{array}$} & \multirow{2}{*}{$\begin{array}{c}\text { Pneu- } \\
\text { mo- } \\
\text { cocci } \\
\text { killed }\end{array}$} & \multirow{2}{*}{$\begin{array}{l}\text { Op- } \\
\text { sonic } \\
\text { index }\end{array}$} & \multirow{2}{*}{$\begin{array}{c}\text { Mouse } \\
\text { protec- } \\
\text { tion }\end{array}$} & \multirow{2}{*}{$\begin{array}{c}\text { Ag- } \\
\text { glu- } \\
\text { ti- } \\
\text { nins }\end{array}$} & \multirow{2}{*}{ Mode } & \multirow{2}{*}{ Day } \\
\hline & & & & & & & & Free & Total & & & & & & & \\
\hline & & & $\begin{array}{l}\text { hours } \\
\text { after } \\
\text { onset }\end{array}$ & hours & grams & & & \multicolumn{2}{|c|}{ mgm. per $100 \mathrm{cc}$. } & & & & & & & \\
\hline 1 & F 51 & S P. & 117 & 144 & 31 & $\begin{array}{r}116 \\
140 \\
168 \\
9 \\
10 \\
14\end{array}$ & $\begin{array}{l}+ \\
0 \\
0 \\
0 \\
0\end{array}$ & $\begin{array}{r}11.8 \\
10.5 \\
8.1 \\
9.1\end{array}$ & $\begin{array}{r}12.9 \\
12.3 \\
9.6 \\
10.5\end{array}$ & $\begin{array}{c}0 \\
10^{5} \\
10^{5} \\
\\
10^{6} \\
10^{6}\end{array}$ & $\begin{array}{c}0 \\
10^{8} \\
10^{4} \\
\\
10^{6} \\
10^{6}\end{array}$ & $\begin{array}{l}0.16 \\
0.02 \\
0 \\
1.4 \\
++\end{array}$ & $\begin{array}{c}0 \\
0 \\
0 \\
0 \\
10^{2} \\
10^{4}\end{array}$ & $\begin{array}{r}0 \\
0 \\
0 \\
4 \\
32 \\
16\end{array}$ & Crisis & 161 \\
\hline 2 & M 42 & S.P. & 116 & 30 & 10 & $\begin{array}{r}116 \\
137 \\
161 \\
10 \\
13 \\
16 \\
23\end{array}$ & 0 & $\begin{array}{l}6.2 \\
8.0\end{array}$ & $\begin{array}{l}8.3 \\
9.9\end{array}$ & $\begin{array}{c}0 \\
10^{4} \\
10^{4} \\
10^{4} \\
10^{4}\end{array}$ & $\begin{array}{c}0 \\
10 \\
10^{2} \\
10^{4} \\
10^{4}\end{array}$ & $\begin{array}{l}0.9 \\
0.5 \\
0.5 \\
0.5 \\
\\
0\end{array}$ & $\begin{array}{r}0 \\
0 \\
0 \\
0 \\
10 \\
0\end{array}$ & $\begin{array}{l}0 \\
0 \\
0 \\
0 \\
0 \\
2 \\
0\end{array}$ & Lysis & $7-14$ \\
\hline $3^{*}$ & F 46 & S.P. & 109 & 148 & 20 & $\begin{array}{r}108 \\
120 \\
8 \\
13\end{array}$ & $\begin{array}{l}0 \\
+ \\
0\end{array}$ & $\begin{array}{l}4.5 \\
9.0 \\
4.3\end{array}$ & $\begin{array}{r}5.0 \\
11.2 \\
5.5\end{array}$ & $\begin{array}{c}0 \\
10^{5} \\
10^{6} \\
10^{6}\end{array}$ & $\begin{array}{c}0 \\
0 \\
10^{5} \\
10^{5}\end{array}$ & $\begin{array}{l}0 \\
0.02 \\
0.04 \\
0.3\end{array}$ & $\begin{array}{r}0 \\
0 \\
10\end{array}$ & $\begin{array}{l}0 \\
0 \\
0 \\
4\end{array}$ & Crisis & 123 \\
\hline 4 & F 48 & S.P. & 58 & 84 & 17 & $\begin{array}{r}58 \\
71 \\
120 \\
9 \\
12\end{array}$ & $\begin{array}{l}0 \\
0\end{array}$ & $\begin{array}{c}4.3 \\
9.5 \\
\text { Tr. }\end{array}$ & $\begin{array}{r}4.3 \\
12.9 \\
\mathrm{Tr} .\end{array}$ & $\begin{array}{c}0 \\
10^{5} \\
10^{6} \\
10^{3} \\
10^{8}\end{array}$ & $\begin{array}{c}0 \\
10^{2} \\
10^{5} \\
10^{8} \\
10^{3}\end{array}$ & $\begin{array}{l}0.02 \\
0 \\
0 \\
0.28 \\
0.32\end{array}$ & $\begin{array}{l}0 \\
0 \\
0 \\
0\end{array}$ & $\begin{array}{l}0 \\
0 \\
0 \\
2 \\
0\end{array}$ & Crisis & 71 \\
\hline $5 \dagger$ & M 72 & S.P. & 89 & 104 & 25 & $\begin{array}{r}89 \\
98 \\
123 \\
11\end{array}$ & $\begin{array}{l}\mathbf{0} \\
\mathbf{0}\end{array}$ & $\begin{array}{l}3.2 \\
5.0 \\
0\end{array}$ & $\begin{array}{l}4.6 \\
9.0 \\
0\end{array}$ & $\begin{array}{c}0 \\
10^{5} \\
10^{4} \\
0\end{array}$ & $\begin{array}{c}0 \\
0 \\
10^{2} \\
0\end{array}$ & $\begin{array}{l}0.22 \\
0.32 \\
0.20 \\
0\end{array}$ & $\begin{array}{l}0 \\
0 \\
0\end{array}$ & $\begin{array}{l}0 \\
0 \\
0 \\
0\end{array}$ & Crisis & 109 \\
\hline $6 \ddagger$ & F 69 & S.P. & 170 & 132 & 38 & $\begin{array}{r}170 \\
180 \\
10 \\
16 \\
20 \\
31\end{array}$ & $\begin{array}{l}0 \\
+ \\
0 \\
0 \\
0\end{array}$ & $\begin{array}{l}2.5 \\
7.8 \\
2.0\end{array}$ & $\begin{array}{l}2.5 \\
8.7 \\
2.8\end{array}$ & $\begin{array}{c}10^{6} \\
10^{8} \\
0\end{array}$ & $\begin{array}{r}10 \\
10 \\
0\end{array}$ & $\begin{array}{l}1.1 \\
0 \\
0.08\end{array}$ & $\begin{array}{r}10 \\
0 \\
0\end{array}$ & $\begin{array}{l}0 \\
0 \\
0 \\
0 \\
0\end{array}$ & Died & 39 \\
\hline 7 & M 69 & S.P. & 46 & 7 & 4 & $\begin{array}{r}46 \\
66 \\
9 \\
14\end{array}$ & 0 & 3.5 & 4.2 & $\begin{array}{l}10^{5} \\
10^{6}\end{array}$ & $\begin{array}{l}10^{8} \\
10^{6}\end{array}$ & $\begin{array}{l}0.08 \\
0.08\end{array}$ & $\begin{array}{c}0 \\
10^{2} \\
10^{4} \\
10^{5}\end{array}$ & $\begin{array}{r}0 \\
2 \\
32 \\
32\end{array}$ & Crisis & 72 \\
\hline
\end{tabular}


TABLE VIII-Continued

\begin{tabular}{|c|c|c|c|c|c|c|c|c|c|c|c|c|c|c|c|c|}
\hline \multirow{3}{*}{$\underset{\text { ber }}{\text { Num- }}$} & \multirow{3}{*}{$\begin{array}{l}\text { Age } \\
\text { and } \\
\text { sex }\end{array}$} & \multirow{3}{*}{ Therapy } & \multirow{3}{*}{\begin{tabular}{|l|} 
First \\
dose
\end{tabular}} & \multirow{3}{*}{$\begin{array}{c}\text { Inter- } \\
\text { val } \\
\text { first to } \\
\text { last } \\
\text { dose }\end{array}$} & \multirow{3}{*}{ Amount } & \multicolumn{9}{|c|}{ Results of tests } & \multicolumn{2}{|c|}{ Termination } \\
\hline & & & & & & \multirow{2}{*}{$\begin{array}{c}\text { Day } \\
\text { of } \\
\text { dis- } \\
\text { ease }\end{array}$} & \multirow{2}{*}{$\begin{array}{c}\text { Blood } \\
\text { cul- } \\
\text { ture }\end{array}$} & \multicolumn{2}{|c|}{$\begin{array}{l}\text { Blood sulfa- } \\
\text { pyridine }\end{array}$} & \multirow{2}{*}{$\left|\begin{array}{c}\text { Growth } \\
\text { inhibi- } \\
\text { tion }\end{array}\right|$} & \multirow{2}{*}{$\begin{array}{c}\text { Pneu- } \\
\text { mo- } \\
\text { coci } \\
\text { killed }\end{array}$} & \multirow{2}{*}{$\begin{array}{l}\text { Op- } \\
\text { sonic } \\
\text { index }\end{array}$} & \multirow{2}{*}{$\begin{array}{c}\text { Mouse } \\
\text { protec- } \\
\text { tion }\end{array}$} & \multirow{2}{*}{$\begin{array}{c}\text { Ag- } \\
\text { glu- } \\
\text { ti- } \\
\text { nins }\end{array}$} & \multirow{2}{*}{ Mode } & \multirow{2}{*}{ Day } \\
\hline & & & & & & & & Free & Total & & & & & & & \\
\hline 8 & F 37 & S.P. & $\mid \begin{array}{c}\text { hours } \\
\text { after } \\
\text { onset } \\
36\end{array}$ & $\begin{array}{c}\text { hours } \\
72\end{array}$ & $\begin{array}{c}\text { grams } \\
18\end{array}$ & $\begin{array}{r}35 \\
57 \\
7 \\
10\end{array}$ & $\begin{array}{l}0 \\
0\end{array}$ & $\begin{array}{l}1.5 \\
0\end{array}$ & $\begin{array}{l}3.8 \\
0\end{array}$ & $\begin{array}{l}10^{5} \\
10^{5} \\
10^{4}\end{array}$ & $\begin{array}{l}10^{5} \\
10^{5} \\
10^{4}\end{array}$ & $\begin{array}{l}0.46 \\
0.16 \\
5.1\end{array}$ & $\begin{array}{c}10^{2} \\
0 \\
10^{5} \\
10^{5}\end{array}$ & $\begin{array}{r}2 \\
2 \\
16 \\
64\end{array}$ & Crisis & 48 \\
\hline 98 & M 55 & S.P. & 146 & 60 & 15 & $\begin{array}{r}145 \\
165 \\
189 \\
212 \\
11\end{array}$ & $\begin{array}{l}1 \\
0 \\
0 \\
0\end{array}$ & $\begin{array}{l}6.8 \\
6.9 \\
6.9 \\
0\end{array}$ & $\begin{array}{r}8.7 \\
10.1 \\
11.1 \\
3.7\end{array}$ & $\begin{array}{l}10^{4} \\
10^{6} \\
10^{6} \\
10^{6} \\
10^{5}\end{array}$ & $\begin{array}{l}10^{4} \\
10^{6} \\
10^{6} \\
10^{6} \\
10^{6}\end{array}$ & $\begin{array}{l}0.08 \\
0.68 \\
1.0 \\
2.1 \\
1.6\end{array}$ & $\begin{array}{l}10 \\
10 \\
10 \\
10^{4} \\
10^{3}\end{array}$ & $\begin{array}{r}0 \\
8 \\
+ \\
64 \\
64\end{array}$ & Crisis & 185 \\
\hline 9a\|l & & S.P. & 66 & 72 & 18 & $\begin{array}{r}65 \\
89 \\
142\end{array}$ & 0 & $\begin{array}{l}5.7 \\
2.9\end{array}$ & $\begin{array}{l}8.6 \\
4.8\end{array}$ & $\begin{array}{l}10 \\
10^{5}\end{array}$ & $\begin{array}{l}10 \\
10\end{array}$ & $\begin{array}{l}0.16 \\
0.26\end{array}$ & $\begin{array}{l}\mathbf{0} \\
0 \\
0\end{array}$ & $\begin{array}{l}0 \\
0 \\
0\end{array}$ & Crisis & 77 \\
\hline 10 & M 43 & S.P. & $\begin{array}{r}4 \\
19\end{array}$ & $\begin{array}{r}72 \\
9\end{array}$ & $\begin{array}{l}18 \\
45\end{array}$ & $\begin{array}{r}4 \\
30 \\
12 \\
21 \\
29\end{array}$ & 0 & $\begin{array}{l}2.1 \\
5.3\end{array}$ & $\begin{array}{l}5.2 \\
6.9\end{array}$ & $\begin{array}{l}10^{4} \\
10^{6} \\
10^{8} \\
10^{6} \\
10^{4}\end{array}$ & $\begin{array}{l}10^{4} \\
10^{3} \\
10^{3} \\
10^{5} \\
10^{2}\end{array}$ & $\begin{array}{l}0 \\
0.04 \\
0 \\
0.04 \\
0.26\end{array}$ & $\begin{array}{l}\mathbf{0} \\
\mathbf{0} \\
\mathbf{0} \\
\mathbf{0} \\
\mathbf{0}\end{array}$ & $\begin{array}{l}\mathbf{0} \\
0 \\
0 \\
0 \\
0\end{array}$ & Lysis & $3-38$ \\
\hline 11 & M 75 & $\underset{\text { Serum }}{\text { S.P. }}$ & $\begin{array}{l}105 \\
109\end{array}$ & $\begin{array}{r}156 \\
6\end{array}$ & $\begin{array}{c}32 \\
500 \text { th.u. }\end{array}$ & $\begin{array}{r}105 \\
124 \\
17\end{array}$ & $\begin{array}{l}0 \\
0\end{array}$ & 6.6 & 6.8 & $\begin{array}{c}0 \\
10^{7} \\
10^{6}\end{array}$ & $\begin{array}{c}0 \\
10^{4} \\
10^{5}\end{array}$ & $\begin{array}{l}0 \\
0.7 \\
0.3\end{array}$ & $\begin{array}{c}0 \\
10^{6} \\
10^{6}\end{array}$ & $\begin{array}{r}0 \\
32 \\
2\end{array}$ & Crisis & 155 \\
\hline $12 \pi$ & M 56 & $\begin{array}{c}\text { S.P. } \\
\text { Serum }\end{array}$ & $\begin{array}{l}50 \\
66\end{array}$ & $\begin{array}{l}84 \\
31\end{array}$ & $\begin{array}{c}19 \\
180 \text { th.u. }\end{array}$ & \begin{tabular}{|r|}
50 \\
66 \\
84 \\
111 \\
13 \\
16
\end{tabular} & $\begin{array}{l}\mathbf{0} \\
\mathbf{0}\end{array}$ & $\begin{array}{l}7.1 \\
4.5 \\
6.7\end{array}$ & $\begin{array}{l}9.0 \\
5.5 \\
7.4\end{array}$ & $\begin{array}{c}0 \\
10^{5} \\
10^{6} \\
10^{8}\end{array}$ & $\begin{array}{c}0 \\
10 \\
10^{3} \\
10^{5}\end{array}$ & $\begin{array}{l}0 \\
0 \\
2.1 \\
2.9\end{array}$ & $\begin{array}{c}0 \\
0 \\
10^{2} \\
10^{3} \\
10^{3} \\
10\end{array}$ & $\begin{array}{l}0 \\
0 \\
2 \\
8 \\
2 \\
0\end{array}$ & Died & 17 \\
\hline $13^{* *}$ & F 64 & \begin{tabular}{|c|} 
S.P. \\
Serum
\end{tabular} & $\begin{array}{l}153 \\
154\end{array}$ & $\begin{array}{r}17 \\
4\end{array}$ & $\begin{array}{c}47 \\
160 \text { th.u. }\end{array}$ & \begin{tabular}{|r|}
153 \\
8 \\
12 \\
26 \\
35
\end{tabular} & $\begin{array}{l}0 \\
0 \\
0\end{array}$ & $\begin{array}{l}5.6 \\
0\end{array}$ & $\begin{array}{l}8.8 \\
0\end{array}$ & $\begin{array}{l}10^{3} \\
10^{7} \\
10^{4} \\
10^{6}\end{array}$ & $\begin{array}{l}10^{2} \\
10^{5} \\
10^{4} \\
10^{6}\end{array}$ & $\begin{array}{l}0 \\
0.4 \\
2.5 \\
3.5\end{array}$ & $\begin{array}{c}0 \\
10^{6} \\
10^{2}\end{array}$ & $\begin{array}{r}0 \\
8 \\
16 \\
4 \\
4\end{array}$ & Lysis & $7-25$ \\
\hline 14 & F 50 & $\begin{array}{c}\text { S.P. } \\
\text { Serum }\end{array}$ & $\begin{array}{l}30 \\
55\end{array}$ & $\begin{array}{r}72 \\
4\end{array}$ & $\begin{array}{c}15 \\
6 C \text { th.u. }\end{array}$ & $\begin{array}{r}30 \\
51 \\
75 \\
9 \\
16\end{array}$ & $\begin{array}{l}0 \\
0\end{array}$ & $\begin{array}{l}7.9 \\
5.2\end{array}$ & $\begin{array}{r}10.0 \\
9.3\end{array}$ & $\begin{array}{l}10^{3} \\
10^{6} \\
10^{8} \\
10^{8}\end{array}$ & $\begin{array}{l}10^{3} \\
10^{5} \\
10^{2} \\
10^{3}\end{array}$ & $\begin{array}{c}0.10 \\
0.06 \\
+ \\
+\end{array}$ & $\begin{array}{c}0 \\
10^{2} \\
10^{3} \\
10^{5}\end{array}$ & $\begin{array}{r}0 \\
0 \\
8 \\
16 \\
32\end{array}$ & Crisis & 68 \\
\hline
\end{tabular}

* Irrational 2nd to 4th day after crisis.

† No protection with homologous strain in each instance.

$\mp$ Developed persistent nitrogen retention and edema after 5 days of treatment.

Same results in opsonic and killing tests with blood culture strain.

Recurrence after 6 months. No protection with sputum strain.

II Alcoholism and delirium tremens.

** Drug given intermittently.

tinins were not demonstrable in 2 of the patients (Numbers 1 and 4), the last observation having been made on the eleventh day in each instance. These antibodies usually did not appear until the seventh day or later. In 1 of the 2 cases in which agglutinins were found on the fifth day or earlier
(Number 9) the time of onset was not well defined and may have been several days earlier than is indicated in the chart. In Case 8 the only specific therapy consisted of an intravenous injection of a glucose-sulfapyridine solution containing the equivalent of 5 grams of sulfapyridine. This pa- 
tient improved gradually and was symptom free within 28 hours after the injection but protective antibodies did not appear until 8 days after the patient was afebrile. The solution used was probably inert when given intravenously (7).

Previous studies of the antibody response in patients with pneumococcus Type VIII pneumonia treated without serum or sulfapyridine have been previously reported (8). They are in essential agreement with the present findings.

Type III Cases. As shown in previous studies on patients treated without serums or drugs (8),

TABLE IX

Additional patients with pneumococcus Type III pneumonia treated with sulfapyridine

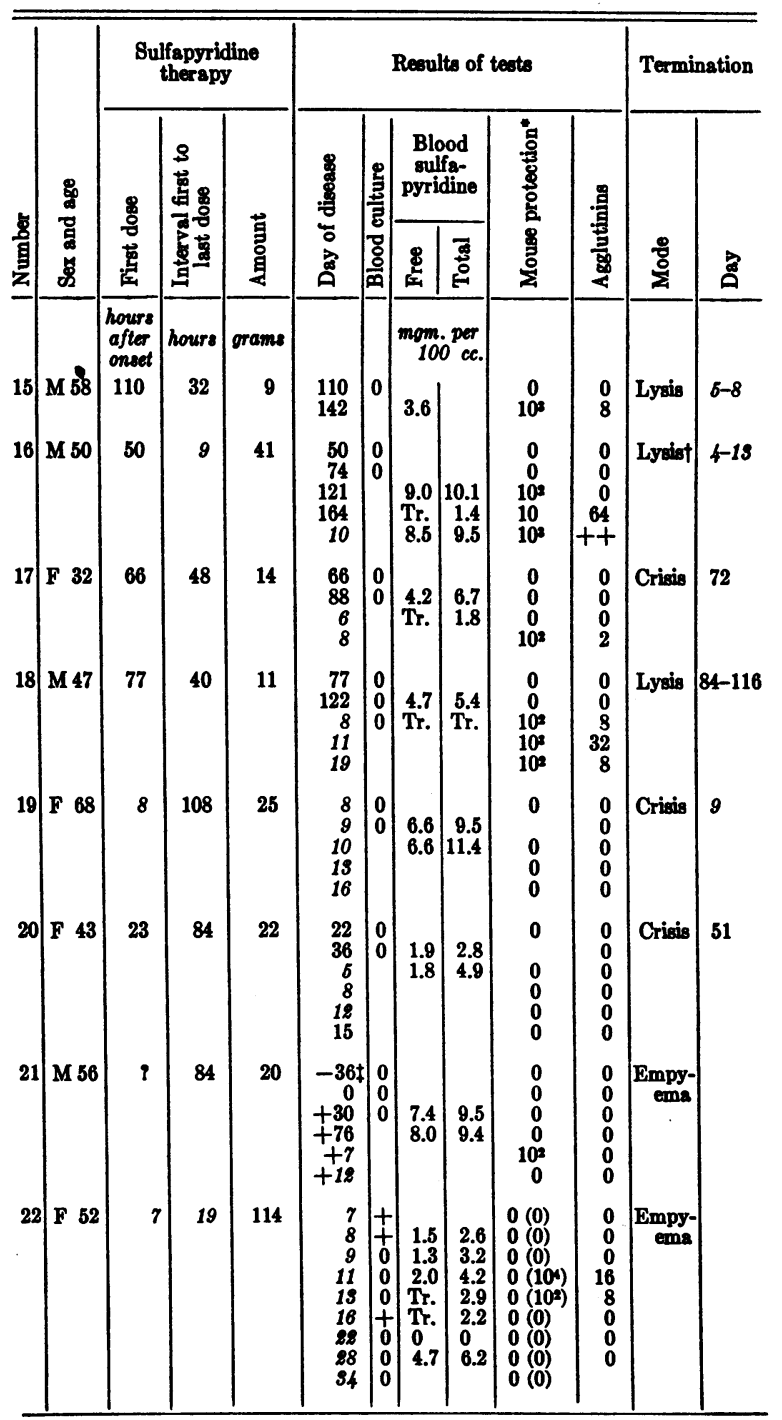

TABLE IX-Continued

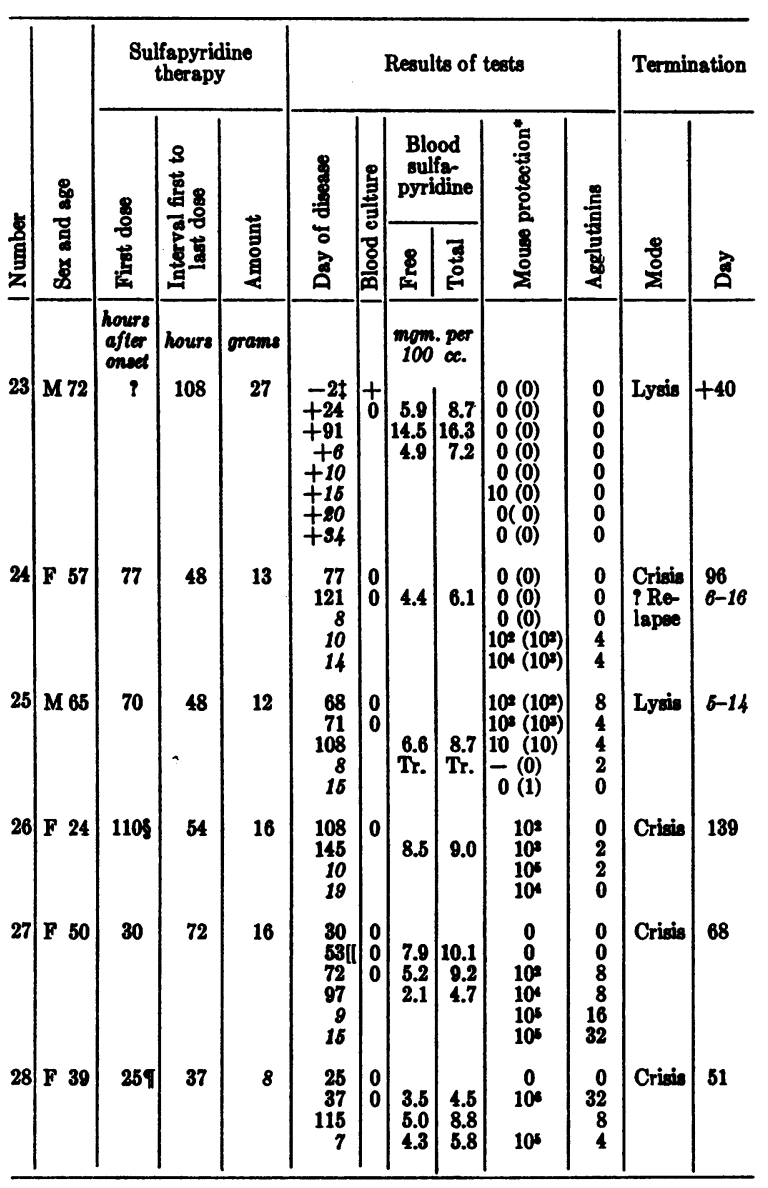

* Numbers in parentheses represent protection with patient's own pneumococcus.

$t$ Vomiting and irrational on 6 th to 9 th day.

$¥$ From beginning of treatment.

8 Otitis media (Pn. III) before treatment.

II Blood 2 hours before 60,000 units of serum given in 5 hours.

I Serum started at same time, 320,000 units given in 6 hours.

and on patients treated with sulfanilamide with or without serum (9), the antibody response to Type III pneumococcus pneumonia is considerably more variable than in other types. The same variability of response has been found in the cases treated with sulfapyridine. In Tables VIII and IX are presented the results of the various antibody determinations in 28 of the cases due to this type that were studied. These cases will serve to illustrate the variety of the responses noted. The findings in the 14 cases on whose blood bactericidal and opsonic tests were carried out are shown in Table VIII. They include 4 
patients treated with serum in addition to sulfapyridine. One-half of the cases tested had bactericidal activity in the blood before treatment was begun. In 2 of them (Numbers 8, 9) the early pneumococcidal action was associated with mouse protection and in 1 there were agglutinins demonstrated at the same time.

The findings in all of the cases were similar in most respects to those previously reported in cases of Type III pneumococcus pneumonia when sulfanilamide was used instead of sulfapyridine. However, there was one significant difference. In the bloods obtained following sulfanilamide administration, but before the development of heatstable antibodies (protection, agglutinins, opsonins), there was marked bacteriostasis but little or no bactericidal action was demonstrable. After sulfapyridine therapy on the other hand, high degrees of killing occurred when the concentration of the drug was high and moderate numbers of pneumococci were killed in the bloods which had low concentration of sulfapyridine.

A few findings of interest in some of the cases may be mentioned. In Case 4 pneumococcus killing was absent before treatment. This property was present during the administration of sulfapyridine and persisted after treatment when the drug could no longer be demonstrated in the circulation and in spite of the fact that no other antibodies were demonstrable. In Cases 5 and 6 , pneumococcidal action was no longer demonstrable after the sulfapyridine was discontinued. In Case 6 there were no preliminary tests done before treatment was begun. However, the blood culture taken at the time of the first dose of sulfapyridine was sterile and the second one taken 10 hours later was positive for Type III pneumococcus. In this case nitrogen retention and edema developed following sulfapyridine treatment and after the pneumococcic infection had apparently subsided completely. Death occurred after several weeks and resulted for the most part from this complication. In Case 10 observations continued for 4 weeks during which time no agglutinins or protection developed and the titer of pneumococcus killing dropped below its original level after the sulfapyridine was discontinued.

Case 9 is of special interest since in this case there was a recurrence of Type III pneumococcic pneumonia after an interval of 6 months. The blood culture was positive during the first attack but blood taken at this time and before treatment showed considerable pneumococcidal action and some mouse protection. High titer of protective antibody and agglutinins developed after the symptoms subsided. The patient was not seen during the second attack until the middle of the third day of illness. X-rays, which after the first attack had shown the lesion in the lung to have cleared, again showed pneumonic consolidation. The sputum was rusty and showed Type III pneumococci in pure culture but the blood culture taken at this time was sterile. Studies of the blood at the same time showed only a minimum of pneumococcidal action and no agglutinins or protection. None of these antibodies developed during the next 3 days although the symptoms subsided rapidly and completely and the patient left the hospital shortly thereafter.

Among the 28 cases listed in Tables VIII and IX, no protective antibodies could be demonstrated in any of the tests in 6 cases and protection against 10 fatal doses developed in 4 others. Agglutinins were not demonstrated in 8 cases and only minimum titers developed in 4 others. Protective antibody occurred on or before the sixth day just as often in bloods taken before treatment as in those obtained 24 hours or more after the beginning of sulfapyridine therapy. Agglutinins usually developed on the sixth day or later and this was true regardless of whether or not sulfapyridine had previously been instituted.

In 5 patients protection tests were carried out on the same serums with both the stock and the homologous strain of Type III pneumococcus. ${ }^{1}$ In 4 of these cases (Numbers 5, 23, 24, 25) the results were in essential agreement. In 1 case, however, protective antibodies were demonstrated on 2 occasions with the homologous strain but not with the stock strain. Agglutinins, on the other hand, were demonstrated with the stock strain in both of these blood samples.

\section{Three-hour tests}

In a number of cases in which bactericidal tests were done, plates were poured from duplicate

1 The homologous strains were passed through mice daily for $\mathbf{2}$ or more weeks and were of maximum virulence at the time of the tests. 
tubes of blood inoculated with various numbers of organisms after 3 hours' rotation in the incubator. The results in a representative group of cases,

TABLE $X$

Results of "three-hour pneumococcidal tests" in patients with pneumococcus Type III and Type V pneumonia treated with sulfapyridine with or without specific immune serum, and a comparison with other antibodies

\begin{tabular}{|c|c|c|c|c|c|c|c|c|c|c|c|c|}
\hline \multirow{4}{*}{ 苞 } & \multirow{4}{*}{ 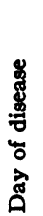 } & \multirow{4}{*}{ 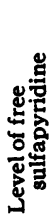 } & \multirow{2}{*}{\multicolumn{2}{|c|}{$\begin{array}{c}\text { Growth } \\
\text { inhibi- } \\
\text { tion }\end{array}$}} & \multirow{4}{*}{ 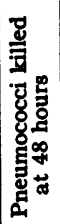 } & \multirow{4}{*}{ 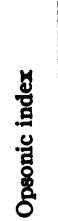 } & \multirow{4}{*}{ 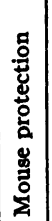 } & \multirow{4}{*}{ 总 } & \multirow{3}{*}{\multicolumn{4}{|c|}{$\frac{\text { Results of 3-hour test }}{\begin{array}{c}\text { Number of colonies } \\
\text { from original } \\
\text { inoculum of: }\end{array}}$}} \\
\hline & & & & & & & & & & & & \\
\hline & & & \multirow{2}{*}{ 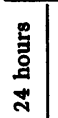 } & \multirow{2}{*}{ 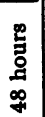 } & & & & & & & & \\
\hline & & & & & & & & & $10^{6}$ & $10^{5}$ & $10^{4}$ & $10^{2}$ \\
\hline
\end{tabular}

TYPE III CASES

\begin{tabular}{|c|c|c|c|c|c|c|c|c|c|c|c|c|}
\hline & & & & & & & & & & & & \\
\hline 1 & $\begin{array}{l}116 \\
140 \\
168 \\
10 \\
14\end{array}$ & $\begin{array}{r}11.8 \\
10.5 \\
9.1\end{array}$ & $\begin{array}{c}0 \\
10^{5} \\
10^{6} \\
10^{6} \\
10^{5}\end{array}$ & $\begin{array}{c}0 \\
10^{5} \\
10^{6} \\
10^{6} \\
10^{5}\end{array}$ & $\begin{array}{c}0 \\
10^{5} \\
10^{4} \\
10^{6} \\
10^{5}\end{array}$ & $\begin{array}{l}0.16 \\
0.02 \\
0 \\
1.4 \\
++\end{array}$ & $\begin{array}{c}0 \\
0 \\
10^{2} \\
10^{4}\end{array}$ & $\begin{array}{r}0 \\
0 \\
0 \\
32 \\
16\end{array}$ & $\begin{array}{c}\infty \\
\infty \\
\mathbf{3 6 0} \\
\mathbf{8 1}\end{array}$ & & $\begin{array}{r}\infty \\
4000 \\
0 \\
2 \\
1\end{array}$ & $\begin{array}{c}680 \\
0 \\
0\end{array}$ \\
\hline 2 & $\begin{array}{r}116 \\
137 \\
161 \\
10 \\
16\end{array}$ & $\begin{array}{l}6.2 \\
8.0\end{array}$ & $\begin{array}{c}0 \\
10^{4} \\
10^{8} \\
10^{4} \\
10^{4}\end{array}$ & $\begin{array}{c}0 \\
10^{4} \\
10^{4} \\
10^{4} \\
10^{4}\end{array}$ & $\begin{array}{c}0 \\
10 \\
10^{2} \\
10^{4} \\
10^{4}\end{array}$ & $\begin{array}{l}0.9 \\
0.5 \\
0.5 \\
0.5 \\
0\end{array}$ & $\begin{array}{r}0 \\
0 \\
10 \\
10\end{array}$ & $\begin{array}{l}\mathbf{0} \\
\mathbf{0} \\
\mathbf{0} \\
\mathbf{0} \\
\mathbf{2}\end{array}$ & & $\begin{array}{c}\infty \\
\infty \\
\infty \\
\mathbf{3 4 0}\end{array}$ & & $\begin{array}{c}1500 \\
800 \\
2000 \\
0 \\
0\end{array}$ \\
\hline 3 & $\begin{array}{r}108 \\
120 \\
8 \\
19\end{array}$ & $\begin{array}{l}4.5 \\
9.0 \\
4.3\end{array}$ & $\begin{array}{c}0 \\
10^{6} \\
10^{6} \\
10^{6}\end{array}$ & $\begin{array}{c}0 \\
10^{5} \\
10^{6} \\
10^{6}\end{array}$ & $\begin{array}{c}\mathbf{0} \\
\mathbf{0} \\
10^{5} \\
10^{6}\end{array}$ & $\begin{array}{l}0 \\
0.02 \\
0.02 \\
0.32\end{array}$ & $\begin{array}{r}0 \\
0 \\
10\end{array}$ & $\begin{array}{l}\mathbf{0} \\
\mathbf{0} \\
\mathbf{0} \\
\mathbf{4}\end{array}$ & & $\begin{array}{c}\infty \\
\infty \\
0 \\
6\end{array}$ & & $\begin{array}{c}2000 \\
1600 \\
0 \\
0\end{array}$ \\
\hline 4 & $\begin{array}{r}58 \\
71 \\
120 \\
9 \\
12\end{array}$ & $\begin{array}{l}4.3 \\
9.5 \\
\text { Tr. }\end{array}$ & $\begin{array}{c}0 \\
10^{5} \\
10^{8} \\
10^{6} \\
10^{4}\end{array}$ & $\begin{array}{c}0 \\
10^{5} \\
10^{6} \\
10^{3} \\
10^{3}\end{array}$ & $\begin{array}{c}0 \\
10^{2} \\
10^{4} \\
10^{3} \\
10^{3}\end{array}$ & $\begin{array}{l}0.02 \\
0 \\
0 \\
0.28 \\
0.32\end{array}$ & $\begin{array}{l}\mathbf{0} \\
\mathbf{0} \\
\mathbf{0}\end{array}$ & $\begin{array}{l}\mathbf{0} \\
\mathbf{0} \\
\mathbf{0} \\
\mathbf{2} \\
\mathbf{0}\end{array}$ & & $\begin{array}{c}\infty \\
87 \\
22\end{array}$ & & $\begin{array}{r}1200 \\
61 \\
0 \\
0 \\
0\end{array}$ \\
\hline 5 & $\begin{array}{r}89 \\
98 \\
123 \\
11\end{array}$ & $\begin{array}{l}3.2 \\
5.9 \\
0\end{array}$ & $\begin{array}{c}0 \\
10^{6} \\
10^{4} \\
0\end{array}$ & $\begin{array}{c}0 \\
10^{5} \\
10^{4} \\
0\end{array}$ & $\begin{array}{c}0 \\
0 \\
10^{2} \\
0\end{array}$ & $\begin{array}{l}0.22 \\
0.32 \\
0.20 \\
0\end{array}$ & $\begin{array}{l}0 \\
0\end{array}$ & $\begin{array}{l}\mathbf{0} \\
\mathbf{0} \\
\mathbf{0} \\
\mathbf{0}\end{array}$ & & $\begin{array}{l}\infty \\
\infty \\
\infty \\
\infty\end{array}$ & & $\begin{array}{r}400 \\
95 \\
61 \\
400\end{array}$ \\
\hline 8 & $\begin{array}{r}35 \\
57 \\
7\end{array}$ & ${ }_{0}^{1.5}$ & $\begin{array}{l}10^{6} \\
10^{6} \\
10^{4}\end{array}$ & $\begin{array}{l}10^{5} \\
10^{5} \\
10^{4}\end{array}$ & $\begin{array}{l}10^{5} \\
10^{5} \\
10^{4}\end{array}$ & $\begin{array}{l}0.46 \\
0.16 \\
5.1\end{array}$ & $\begin{array}{c}10^{2} \\
0 \\
10^{5}\end{array}$ & $\begin{array}{r}2 \\
2 \\
16\end{array}$ & & $\begin{array}{l}0 \\
5 \\
0\end{array}$ & & $\begin{array}{l}\mathbf{0} \\
\mathbf{0} \\
\mathbf{0}\end{array}$ \\
\hline $9 a$ & $\begin{array}{r}65 \\
142\end{array}$ & 2.9 & $\begin{array}{l}10 \\
10^{5}\end{array}$ & $\begin{array}{l}10 \\
10^{6}\end{array}$ & $\begin{array}{l}10 \\
10\end{array}$ & $\begin{array}{l}0.16 \\
0.26\end{array}$ & $\begin{array}{l}\mathbf{0} \\
\mathbf{0}\end{array}$ & $\begin{array}{l}\mathbf{0} \\
0\end{array}$ & & $\begin{array}{l}\infty \\
\infty\end{array}$ & & $\begin{array}{r}36 \\
7\end{array}$ \\
\hline 10 & 29 & & $10^{4}$ & $10^{4}$ & $10^{2}$ & 0.26 & 0 & 0 & 1200 & & 0 & 0 \\
\hline 14 & $\begin{array}{r}30 \\
51 \\
9 \\
16\end{array}$ & 7.9 & $\begin{array}{l}10^{8} \\
10^{6} \\
10^{8} \\
10^{3}\end{array}$ & $\begin{array}{l}10^{3} \\
10^{6} \\
10^{5} \\
10^{3}\end{array}$ & $\begin{array}{l}10^{3} \\
10^{5} \\
10^{3} \\
10^{3}\end{array}$ & $\begin{array}{c}0.10 \\
0.06 \\
+ \\
+\end{array}$ & $\begin{array}{c}0 \\
10^{3} \\
10^{5}\end{array}$ & $\begin{array}{r}0 \\
0 \\
16 \\
32\end{array}$ & $\begin{array}{c}\infty \\
2000 \\
4000\end{array}$ & 66 & $\begin{array}{r}0 \\
5 \\
79\end{array}$ & $\begin{array}{l}0 \\
1 \\
0\end{array}$ \\
\hline
\end{tabular}

TYPE V CASES

\begin{tabular}{|c|c|c|c|c|c|c|c|c|c|c|c|}
\hline 2 & $\begin{array}{r}74 \\
135 \\
11\end{array}$ & 3.5 & $\begin{array}{l}10 \\
10^{6} \\
10^{4}\end{array}$ & $\begin{array}{l}10 \\
10^{6} \\
10^{4}\end{array}$ & $\begin{array}{l}10 \\
104 \\
10^{3}\end{array}$ & $\begin{array}{l}\mathbf{0 . 7 4} \\
\mathbf{3 6 . 4}\end{array}$ & $\begin{array}{c}0 \\
0 \\
10^{\circ}\end{array}$ & $\begin{array}{l}\mathbf{0} \\
\mathbf{0} \\
\mathbf{2}\end{array}$ & 2000 & $\begin{array}{l}15 \\
15\end{array}$ & $\begin{array}{l}8 \\
0 \\
0\end{array}$ \\
\hline 3 & $\begin{array}{r}96 \\
107\end{array}$ & 4.5 & $\begin{array}{l}10^{8} \\
10^{7}\end{array}$ & $\begin{array}{l}10^{6} \\
10^{7}\end{array}$ & $\begin{array}{l}10^{8} \\
10^{7}\end{array}$ & $\begin{array}{l}1.58 \\
1.34\end{array}$ & $\begin{array}{r}10 \\
0\end{array}$ & $\begin{array}{l}\mathbf{0} \\
\mathbf{0}\end{array}$ & $\begin{array}{r}10 \\
3\end{array}$ & & $\begin{array}{l}\mathbf{0} \\
\mathbf{0}\end{array}$ \\
\hline 4 & $\begin{array}{r}86 \\
96 \\
120\end{array}$ & $\begin{array}{l}5.3 \\
5.6\end{array}$ & $\begin{array}{l}10^{3} \\
10^{6} \\
10^{6}\end{array}$ & $\begin{array}{l}10^{8} \\
10^{6} \\
10^{4}\end{array}$ & $\begin{array}{l}10^{3} \\
10^{2} \\
10^{3}\end{array}$ & $\begin{array}{l}0.96 \\
0.60 \\
0.80\end{array}$ & $\begin{array}{l}10^{4} \\
10^{6}\end{array}$ & $\begin{array}{l}0 \\
0 \\
2\end{array}$ & $\begin{array}{r}320 \\
33 \\
400\end{array}$ & & $\begin{array}{l}0 \\
0 \\
0\end{array}$ \\
\hline 6 & $\begin{array}{l}20 \\
43 \\
65 \\
88 \\
10\end{array}$ & $\begin{array}{l}\mathbf{5 . 0} \\
\text { Tr. } \\
\text { o }\end{array}$ & $\begin{array}{c}0 \\
10^{5} \\
10^{5} \\
10^{4} \\
10^{6}\end{array}$ & $\begin{array}{c}0 \\
10^{5} \\
10^{6} \\
10^{4} \\
10^{5}\end{array}$ & $\begin{array}{c}0 \\
10^{5} \\
10^{5} \\
10^{4} \\
10^{5}\end{array}$ & $\begin{array}{l}1.5 \\
0.88 \\
0.70 \\
15.4 \\
+\end{array}$ & $\begin{array}{c}0 \\
0 \\
10 \\
106 \\
10^{6}\end{array}$ & $\begin{array}{r}0 \\
0 \\
0 \\
16 \\
8\end{array}$ & $\begin{array}{r}\infty \\
2000 \\
9 \\
20 \\
21\end{array}$ & & $\begin{array}{l}0 \\
0 \\
0 \\
0 \\
0\end{array}$ \\
\hline
\end{tabular}

* Case numbers are same as in Tables IV and VIII which have the relevant data concerning treatment and outcome.
9 of Type III and 4 of Type V, are listed in Table X. These results show clearly that, during the course of treatment, pneumococcus killing due to the action of sulfapyridine and that due to the immune state may be differentiated by the results of the tests. Where there is marked bacteriostasis early and only slight killing after 48 hours the effect is probably due wholly or in part to sulfapyridine. Where there is killing in 3 hours this is due to the immune properties of the serum, these being either acquired spontaneously or introduced passively. The mechanism of the pneumococcidal action when killing of large numbers of pneumococci occurs can be readily differentiated in this manner.

These findings emphasize again the fact that the destruction of pneumococci in the presence of immune bodies is rapid, while such killing when it is due to the presence of sulfapyridine is considerably delayed.

\section{Agglutinin response in sulfapyridine-treated cases of pneumonia associated with other types of pneumococci}

The antibody response of patients with pneumonia due to types of pneumococci other than those already dealt with who were treated without specific serums or chemicals has been reported previously (5). The results of tests for agglutinins in sulfapyridine-treated cases of pneumonia due to pneumococci other than Type I, II, III, V, VII, or VIII are listed in Table XI. Patients who received specific serums in addition are omitted from this table. In general the results, as far as can be ascertained from the small number of cases, did not differ materially from those formerly obtained in the untreated cases. A few findings of interest may be noted. Homologous type-specific agglutinins developed in only 21 of the cases. Two of the bacteremic cases who recovered, Numbers 13 and 39, were among the ones in whom agglutinins were not demonstrated although the last tests in these cases were done on the thirteenth and sixteenth day respectively.

Among the patients who developed agglutinins these antibodies were first demonstrated on the fifth day in 3 cases and on the seventh day or later in the others. In 2 of the cases who developed the antibodies early (Numbers 12 and 14) mini- 
TABLE XI

Agglutinins for homologous type of pneumococcus in sulfapyridine treated patients with pneumonia due to pneumococci of types other than $I, I I, I I I, V, V I I$, or VIII

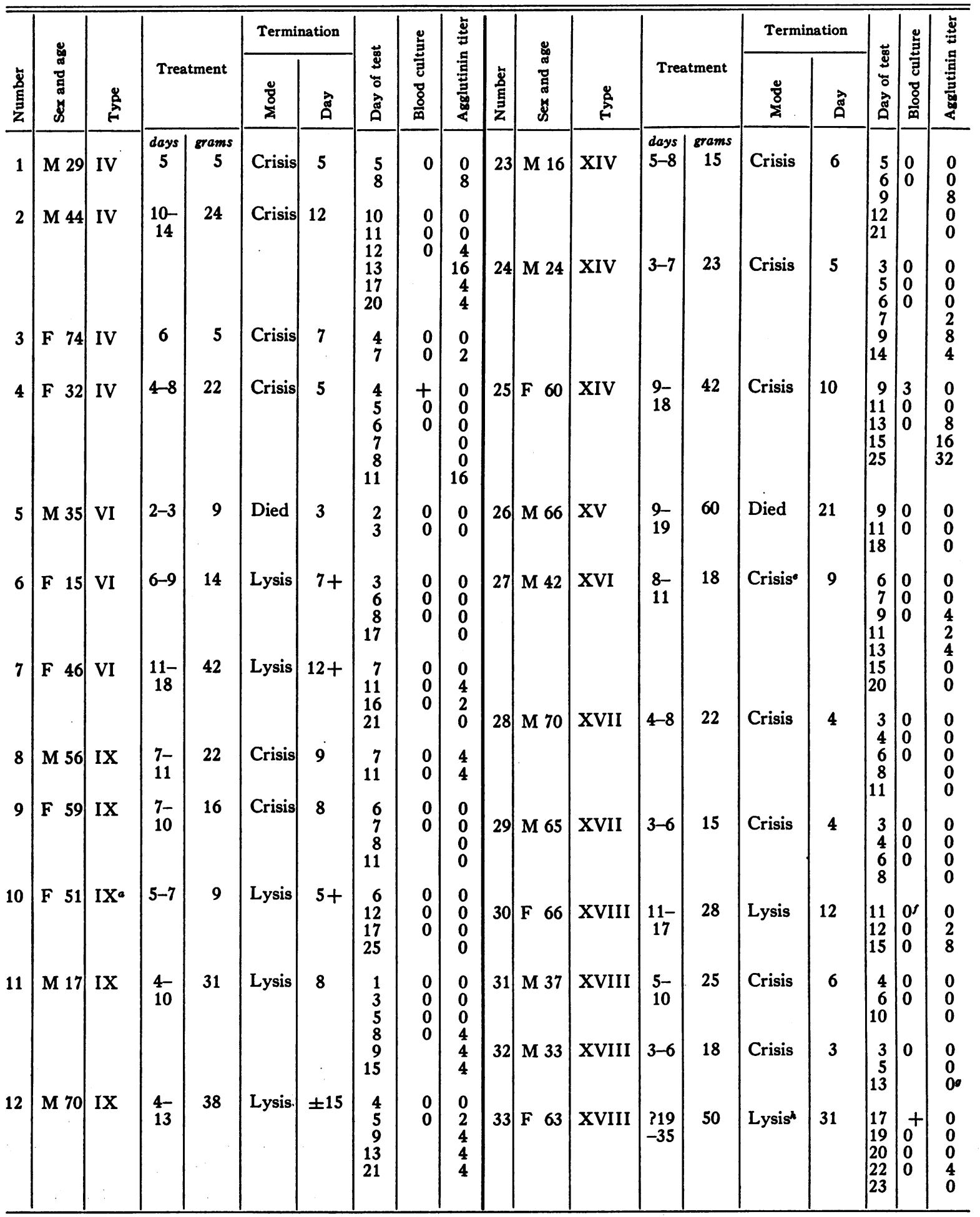


TABLE XI-Continued

\begin{tabular}{|c|c|c|c|c|c|c|c|c|c|c|c|c|c|c|c|c|c|c|c|}
\hline \multirow[b]{2}{*}{ 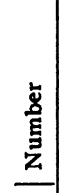 } & \multirow[b]{2}{*}{ 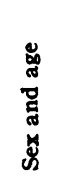 } & \multirow[b]{2}{*}{$\stackrel{\Delta}{\Leftrightarrow}$} & \multirow{2}{*}{\multicolumn{2}{|c|}{ Treatment }} & \multicolumn{2}{|c|}{ Termination } & \multirow[b]{2}{*}{ 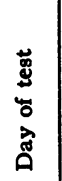 } & \multirow{2}{*}{ 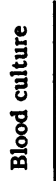 } & \multirow{2}{*}{ 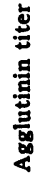 } & \multirow[b]{2}{*}{ 总 } & \multirow[b]{2}{*}{ 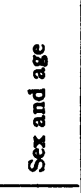 } & \multirow[b]{2}{*}{ 参 } & & & \multicolumn{2}{|c|}{ Termination } & \multirow[b]{2}{*}{ 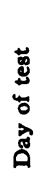 } & \multirow{2}{*}{ 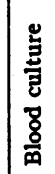 } & \multirow{2}{*}{ 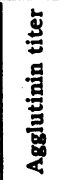 } \\
\hline & & & & & $\frac{\pi}{\Sigma}$ & คे & & & & & & & Trea & ment & ¿ & मे & & & \\
\hline 13 & M 52 & $\mathbf{X}$ & $\begin{array}{c}\text { days } \\
4-\end{array}$ & $\begin{array}{c}\text { grams } \\
42\end{array}$ & Crisis & 7 & 4 & + & 0 & & & & & grams & & & & & \\
\hline & & & & & & & $\begin{array}{r}5 \\
8 \\
13\end{array}$ & $\begin{array}{l}0 \\
0 \\
0\end{array}$ & $\begin{array}{l}0 \\
0 \\
0\end{array}$ & 34 & F 53 & XIX & 4-9 & 26 & Crisis & 8 & $\begin{array}{r}4 \\
6 \\
9 \\
11\end{array}$ & $\begin{array}{l}0 \\
0\end{array}$ & $\begin{array}{l}\mathbf{0} \\
\mathbf{0} \\
\mathbf{0} \\
\mathbf{0}\end{array}$ \\
\hline 14 & M 62 & XI & $3-7$ & 19 & Crisis & 3 & $\begin{array}{r}3 \\
5 \\
10\end{array}$ & 0 & $\begin{array}{l}0 \\
2 \\
0\end{array}$ & 35 & F 31 & XIX & $7-9$ & 11 & Crisis & 9 & $\begin{array}{r}16 \\
7\end{array}$ & 0 & $\begin{array}{l}0 \\
0\end{array}$ \\
\hline 15 & F 19 & XI & $4-5$ & 8 & Crisis & 5 & & 0 & $\begin{array}{l}0 \\
0\end{array}$ & & & & & & & & 12 & & 0 \\
\hline 16 & M 37 & $\mathbf{X I}^{b}$ & $\begin{array}{l}7- \\
11\end{array}$ & 26 & Died & 13 & $\begin{array}{r}9 \\
4 \\
8 \\
11\end{array}$ & $\begin{array}{l}0 \\
0 \\
0\end{array}$ & $\begin{array}{l}8 \\
0 \\
4 \\
2\end{array}$ & 36 & M 34 & XIX & $4-6$ & 13 & Crisis & 6 & $\begin{array}{r}4 \\
6 \\
9 \\
12\end{array}$ & 0 & $\begin{array}{l}0 \\
0 \\
0 \\
0\end{array}$ \\
\hline 17 & F 80 & XI & 2-8 & 24 & Lysis & 3 & $\begin{array}{l}2 \\
8\end{array}$ & $\mathbf{0}$ & $\begin{array}{l}0 \\
0\end{array}$ & 37 & M 44 & $\mathbf{X X}$ & $5-7$ & 12 & Crisis & 6 & $\begin{array}{l}3 \\
5 \\
8\end{array}$ & + & $\begin{array}{l}0 \\
0 \\
8\end{array}$ \\
\hline 18 & M 32 & XII & $\begin{array}{l}6- \\
10\end{array}$ & 19 & Crisis & 7 & 5 & $\begin{array}{l}0 \\
0\end{array}$ & 0 & & & & & & & & 14 & & 16 \\
\hline 19 & F 64 & XIV & $3-7$ & 24 & Died & 7 & $\begin{array}{r}10 \\
15 \\
3 \\
4 \\
5\end{array}$ & $\begin{array}{r}240 \\
+\end{array}$ & $\begin{array}{l}0 \\
0 \\
0 \\
0 \\
0\end{array}$ & 38 & M 59 & $\mathbf{x X}$ & $\begin{array}{l}4- \\
10\end{array}$ & 32 & Lysis & $6+$ & $\begin{array}{r}4 \\
6 \\
10 \\
15 \\
19\end{array}$ & $\begin{array}{l}0 \\
0\end{array}$ & $\begin{array}{l}\mathbf{0} \\
\mathbf{0} \\
\mathbf{0} \\
\mathbf{0} \\
\mathbf{0}\end{array}$ \\
\hline 20 & M 74 & XIV & $\begin{array}{l}? 28 \\
-34\end{array}$ & 53 & Died & 34 & $\begin{array}{l}28 \\
30^{\circ} \\
31 \\
34\end{array}$ & $\begin{array}{r}303 \\
0 \\
0 \\
0\end{array}$ & $\begin{array}{l}\mathbf{0} \\
\mathbf{0} \\
\mathbf{0} \\
\mathbf{0}\end{array}$ & 39 & F 65 & XXI & 5-7 & 10 & Crisis & 6 & $\begin{array}{r}4 \\
5 \\
6 \\
7 \\
9 \\
9\end{array}$ & $\begin{array}{l}+ \\
0 \\
0\end{array}$ & $\begin{array}{l}\mathbf{0} \\
\mathbf{0} \\
\mathbf{0} \\
\mathbf{0} \\
\mathbf{0}\end{array}$ \\
\hline 22 & F 17 & XIV & $5-6$ & 28 & Crisis & 7 & $\begin{array}{l}3 \\
5 \\
8 \\
6\end{array}$ & $\begin{array}{l}\mathbf{0} \\
0\end{array}$ & $\begin{array}{l}\mathbf{0} \\
8 \\
8\end{array}$ & 40 & M 63 & XXIX & $\begin{array}{c}? 3 \\
-10\end{array}$ & 41 & $\begin{array}{l}\text { Lysis } \\
\text { (empy- } \\
\text { ema) }\end{array}$ & 11 & $\begin{array}{r}16 \\
3 \\
5 \\
8\end{array}$ & $\mid \begin{array}{l}0 \\
0 \\
0\end{array}$ & $\begin{array}{l}4 \\
8 \\
2\end{array}$ \\
\hline & & & & & & & $\begin{array}{r}\circ \\
9 \\
11 \\
15\end{array}$ & 0 & $\begin{array}{l}0^{d} \\
0 \\
0\end{array}$ & 41 & F 13 & XXXI & $5-7$ & 11 & Crisis & 5 & $\begin{array}{l}4 \\
6\end{array}$ & 0 & $\begin{array}{l}0 \\
4\end{array}$ \\
\hline
\end{tabular}

a Streptococcus hemolyticus in same and subsequent sputa.

b Sputum positive for tubercle bacilli.

- Meningitis demonstrated on this day.

d Agglutinins for Type V pneumococcus $(1: 8)$ in this and later specimens. None in previous ones. All cases negative for 8 other types.

- Fever 12th to 21 st day.

$f$ Pleural fluid culture Pn. XVIII on 7th and 11th day.

- Agglutinins Pn. I = 2, previous sera negative.

Three bouts of fever; no agglutinins after $23 \mathrm{~d}$ day ( 7 tests).

mal titers were found, and in the third (Case 21) the antibodies were first demonstrated just before sulfapyridine treatment was undertaken. In Case 16 death occurred after agglutinins had developed.

Tests for heterologous antibodies were carried out with one or more types of pneumococci in every case and with several of the frequent types in the serums of all patients who failed to show antibodies for the homologous type. Agglutinins for heterologous types were demonstrated in only 2 cases. In Case 22 Type XIV pneumococci were obtained from the sputum, homologous agglutinins could not be demonstrated but serums 
obtained on the ninth day and later showed agglutinins for Type V pneumococci. Such agglutinins were not present in 2 earlier serums. In Case 32 a low titer of Type I agglutinins was found in the last serum tested.

Two of the patients had other organisms in their sputa which were probably significant with regard to the pulmonary infection. Hemolytic streptococci were found to predominate in all sputa examined in Case 10 and agglutinins for the Type IX pneumococcus which was found in the earlier examination of his sputum were not demonstrated in any of these serums. However, in Case 16, the sputum was strongly positive for tubercle bacilli and also contained Type XI pneumococci. Antibodies for this type developed during the disease but the patient died after a few days.

\section{DISCUSSION}

When two agents of proven efficacy such as type-specific antipneumococcus serum and sulfapyridine are available for the treatment of any severe or highly fatal disease, such as pneumonia, it is most important to determine the relative efficacy of each agent under various conditions. It is equally important to determine whether such agents are more effective when used together than when used separately. While the final test under such circumstances rests in the careful analysis of the response of a large number of cases to therapy, a close study of patients under treatment will reveal many of the factors involved in the action of each of these agents when used separately or in combination. Furthermore, while much can be learned from controlled studies of experimental infections in animals, the conditions in patients, particularly in cases of pneumonia, can hardly be duplicated in animals. It is for that reason that the present studies were undertaken to supplement clinical studies in an attempt to elucidate some aspects of the problems of specific serotherapy and chemotherapy in the pneumococcic pneumonias. It has been shown previously (10) and corroborated in the present studies that the blood of patients with pneumonia may exert bactericidal action against the infecting organism during the course of the disease. This bactericidal action is independent of heat-stable antibodies (agglutinins and mouse protection).
In patients lacking this bactericidal action the blood acquires the ability to kill large numbers of the homologous pneumococcus at the time of recovery and in that event the pneumococcidal action of the blood is usually associated with agglutinins, mouse protective antibodies and opsonins. These latter heat-stable antibodies are also acquired at the time of crisis or later by those patients who previously had pneumococcidal power in the blood. The heat-stable antibodies may be introduced passively in the course of the disease and may thus bring about an artificial crisis. This has been repeatedly demonstrated in the clinical use of specific antipneumococcic serums.

Recent studies (11), which have been confirmed and extended in this laboratory (1), have shown that sulfapyridine exerts marked bacteriostatic and bactericidal effects on pneumococci in artificial media or when added to human blood in vitro. The results of the present studies indicate that blood taken from patients during sulfapyridine therapy has bacteriostatic and bactericidal properties which parallel those found when comparative amounts of sulfapyridine are added to the blood in vitro. This pneumococcidal action of sulfapyridine has been found to be independent of the immune mechanism when the drug is added to blood in vitro, and the same is here shown to be true in the blood of patients under treatment. In both the in vitro experiments and in the present studies with blood taken during treatment it was shown that the effect of the combination of serum and sulfapyridine is greater than when either agent is used alone.

The results of the 3-hour test are of special interest. It was shown previously (1) that the pneumococcidal action of sulfapyridine is a delayed action. It depends on the growth of pneumococci. The fewer the number of organisms present, the more rapid, the more certain, and the more effective is the action of this drug. The pneumococcidal properties associated with the immune mechanism, whether in natural antibodies such as are found in normal serum, in acquired antibodies resulting from infection, or in antibodies passively introduced in therapy, all act rapidly. The action due to the immune mechanism is carried essentially to completion during the "growth phase" of sulfapyridine action (1). 
These findings would indicate very strongly that serum and sulfapyridine, at least with respect to their mode of action, are important complementary weapons in combatting the pneumococcic pneumonias. Whether they are both actually necessary, and the conditions under which each or both may be most effective clinically, are not within the scope of the present discussion.

Aside from the importance of the mechanism of action, this paper is concerned largely with another phase of the use of sulfapyridine. It is obviously important to know whether the immune mechanism is essential for recovery when a bactericidal drug like sulfapyridine is used. Only an indirect answer can be given to this question. The data presented indicate that, when specific antibodies are present, recovery is more rapid. They show further that recovery following sulfapyridine therapy is associated with the development of antibodies in the same manner as in the course of natural recovery without the use of the drug. The antibodies develop apparently with the same frequency as in cases not treated with the drug. It is not possible on the basis of the present data to determine with statistical accuracy whether or not the time of the development of antibodies is shortened under sulfapyridine therapy as compared with the natural development of such antibodies in the course of infection. If there is any difference it is obviously not very striking and does not appear on the surface.

One problem directly faced by the clinician is whether the discontinuance of sulfapyridine treatment before the time of the development of antibodies has any influence on the further course of the illness and whether the occurrence of relapses is thereby encouraged. Relapses have been noted during the course of sulfapyridine therapy and particularly when the drug has been discontinued early. These relapses have probably occurred with more than the expected frequency. If the findings here are of any significance in this respect they would indicate that such relapses might be averted by the early use of immune serum to supplement the drug.

\section{SUMMARY AND CONCLUSIONS}

The results of immune studies in patients with pneumococcic pneumonia treated with sulfapyri- dine are presented. A small number of cases treated with specific serums in addition are also included. Bactericidal and phagocytic tests were carried out in many of the cases associated with Types I, III, and V pneumococci.

The results of the bactericidal tests indicated that the blood of patients undergoing treatment with sulfapyridine has marked bacteriostatic and considerable bactericidal action on the homologous type of pneumococcus. This effect was independent of the immune mechanism residing in the blood. This action of sulfapyridine was the same as that noted when comparable concentrations of the drug are added to artificial media or to human blood in vitro. The greatest and most rapid bactericidal activity occurred in the presence of heatstable antibodies (agglutinins, protection, opsonins).

The results of tests for bactericidal action at the end of 3 hours indicate that the pneumococcidal action resulting from the immune mechanism is exerted rapidly and is practically carried to completion before any bacteriostatic effect of sulfapyridine becomes evident.

The antibody response of patients with pneumococcic pneumonia treated with sulfapyridine, as far as could be determined was comparable in every respect to that resulting from spontaneous recovery. Protective antibodies rarely developed before the sixth day and agglutinins rarely appeared before the seventh day of the disease.

Entirely apart from observed clinical results and only from the point of view of the mechanism of action of serum and sulfapyridine as observed in patients undergoing treatment, the combination of these two agents is the treatment of choice.

This study was carried out with the technical assistance of Mildred W. Barnes and Claire Wilcox. The chemical determinations were made by Margaret A. Adams and Nancy E. Marean.

\section{BIBLIOGRAPHY}

1. Spring, W. C., Jr., Lowell, F. C., and Finland, M., Studies on the action of sulfapyridine on pneumococci. J. Clin. Invest., 1940, 19, 163.

2. Finland, M., and Sutliff, W. D., Specific cutaneous reactions and circulating antibodies in the course of lobar pneumonia. I. Cases receiving no serum therapy. J. Exper. Med., 1931, 54, 637.

3. Finland, M., and Sutliff, W. D., Specific cutaneous 
reactions and circulating antibodies in the course of lobar pneumonia. II. Cases treated with antipneumococcic sera. Ibid., 653.

4. Finland, M., and Winkler, A. W., Antibody response to infections with Type II and the related Type V pneumococcus. J. Clin. Invest., 1934, 13, 97.

5. Winkler, A. W., and Finland, M., Antibody response to infections with the newly classified types of pneumococci. Ibid., 109.

6. Finland, M., Tilghman, R. C., Ruegsegger, J. M., and Dowling, H. F., Clinical and immunological observations in cases of pneumococcus Type VII pneumonia treated with concentrated type-specific antibody. Am. J. M. Sc., 1937, 193, 59.

7. Lowell, F. C., Spring, W. C., and Finland, M., Bac- tericidal action of sodium sulfapyridine and of a glucose-sulfapyridine solution in human blood. J. Clin. Invest., 1940, 19, 215.

8. Finland, M., and Winkler, A. W., Antibody response to infections with Type III and the related Type VIII pneumococcus. J. Clin. Invest., 1934, 13, 79.

9. Finland, M., and Brown, J. W., Immunological studies in patients with pneumococcus Type III pneumonia treated with sulfanilamide and serum. Ibid., 1939, 18, 307.

10. Robertson, O. H., Terrell, E. E., Graeser, J. B., and Cornwell, M. A., The relation of natural humoral antipneumococcal immunity to the inception of lobar pneumonia. J. Exper. Med., 1930, 52, 421.

11. See (1) References 3 to 9. 